\title{
Working
}

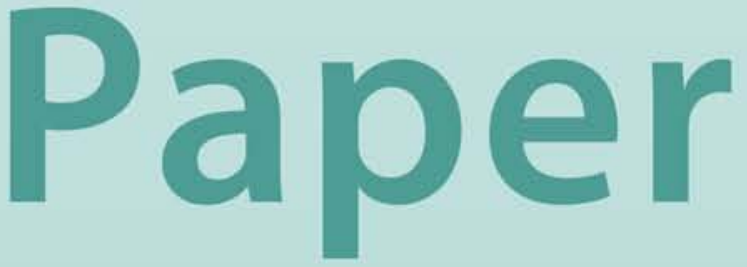




\section{Limits of Floating Exchange Rates: the Role of Foreign Currency Debt and Import Structure}

Pascal Towbin and Sebastian Weber 


\title{
IMF Working Paper
}

\author{
European Department \\ Limits of Floating Exchange Rates: \\ the Role of Foreign Currency Debt and Import Structure \\ Prepared by Pascal Towbin and Sebastian Weber ${ }^{\dagger}$
}

Authorized for distribution by Ashoka Mody

February 2011

This Working Paper should not be reported as representing the views of the IMF. The views expressed in this Working Paper are those of the author(s) and do not necessarily represent those of the IMF or IMF policy. Working Papers describe research in progress by the author(s) and are published to elicit comments and to further debate.

\begin{abstract}
A traditional argument in favor of flexible exchange rates is that they insulate output better from real shocks, because the exchange rate can adjust and stabilize demand for domestic goods through expenditure switching. This argument is weakened in models with high foreign currency debt and low exchange rate pass-through to import prices. The present study evaluates the empirical relevance of these two factors. We analyze the transmission of real external shocks to the domestic economy under fixed and flexible exchange rate regimes for a broad sample of countries in a Panel VAR and let the responses vary with foreign currency indebtedness and import structure. We find that flexible exchange rates do not insulate output better from external shocks if the country imports mainly low pass-through goods and can even amplify the output response if foreign indebtedness is high.
\end{abstract}

JEL Classification Numbers: E30, F33, F34, F41

Keywords: Exchange rate regime, balance sheet effect, pass-through, interacted panel VAR, external shock

Author’s E-Mail Address: pascal.towbin@banque-france.fr; sweber@imf.org

\footnotetext{
${ }^{\dagger}$ This paper has benefited from suggestions by Marcel Fratzscher, Domenico Giannone, Stefan Gerlach, Cedric Tille, Charles Wyplosz, and participants at SSES Congress 2009, RES 2010, CEPII-Brugel Workshop 2010, Banque de France, and Bank of Canada. We also like to thank Harald Anderson, Ken Chikada, Irineu de Carvalho Filho, Atish Ghosh, David Gregorian, Albert Jäger, Mustafa Saiyid, and Jerome Vandenbussche for helpful comments. Part of this research was conducted while both authors were at the Graduate Institute Geneva and funding from the Swiss National Science Foundation is gratefully acknowledged. The views expressed are those of the authors and do not necessarily reflect the views of the institutions they are associated with.
} 


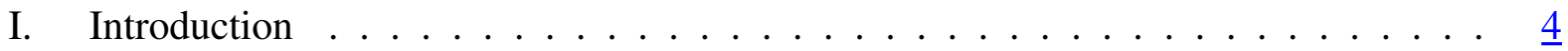

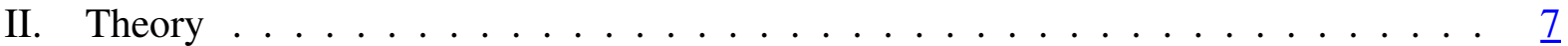

A. IS-LM-BP with Foreign Debt and Incomplete Pass-through . . . . . . . . . . . $\underline{9}$

B. Adjustment to an External Demand Shock . . . . . . . . . . . . . . . 10

1. The Peg ............................. 11

2. The Float . . . . . . . . . . . . . . . . . . . 11

3. Simulation of Responses under Peg and Float . . . . . . . . . . 13

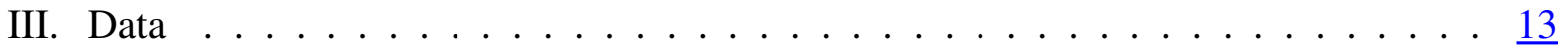

IV. Model and Estimation . . . . . . . . . . . . . . . . . . . 17

A. Empirical Model and Identification . . . . . . . . . . . . . . . . . . 17

B. Interaction Terms . . . . . . . . . . . . . . . . . $\underline{18}$

C. Estimation and Inference . . . . . . . . . . . . . . . . $\underline{20}$

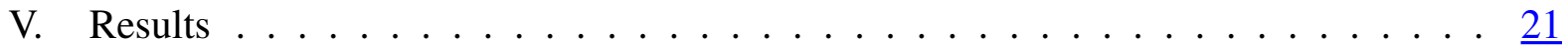

A. Floats versus Pegs . . . . . . . . . . . . . . . . 21

B. The Role of Foreign Currency Debt . . . . . . . . . . . . . . . . $\underline{22}$

C. The Role of Import Structure . . . . . . . . . . . . . . . . . . . . . 27

D. The Joint Role of Foreign Currency Debt and Import Structure . . . . . . . . . $\underline{29}$

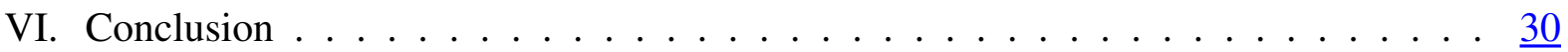

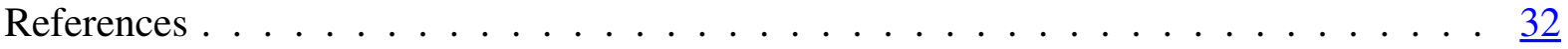

Appendices

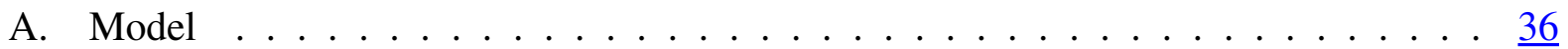

A.1. Workers ...................... . . . . . . . . . . . . . . . .

A.2. Production and Price Setting . . . . . . . . . . . . . $\underline{37}$

A.3. Entrepreneurs . . . . . . . . . . . . . . . . . $\underline{38}$

A.4. Monetary Policy . . . . . . . . . . . . . . . . . . . . . . . . . . . . . . . . . . .

A.5. Market Clearing . . . . . . . . . . . . . . . $\underline{39}$

B. Derivation of the IS-LM-BP Equations . . . . . . . . . . . . . 40

B.1. IS Curve . . . . . . . . . . . . . . . . . . . . . 40

B.2. LM: Money Demand . . . . . . . . . . . . . . . . . . . . 41

B.3. BP: Entrepreneurs . . . . . . . . . . . . . . 42

C. Solving the system ..................... . . 43

C.1. The Peg . . . . . . . . . . . . . . . . . . 44

C.2. The Float . . . . . . . . . . . . . . . . . . . . . . . 45

C.3. The Pure Float . . . . . . . . . . . . . . . . . . . 47

C.4. Evaluating the response of $\partial^{2} y / \partial x \partial \omega \ldots \ldots \ldots \ldots$ 


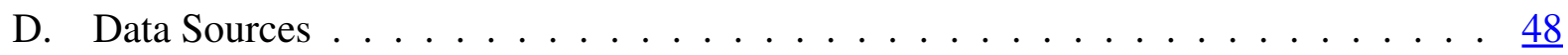

Tables

1. Summary of Theoretical Predictions . . . . . . . . . . . . . . . . 12

2. Output and Investment Response to External Shock, Conditional on the Exchange Rate Regime . . . . . . . . . . . . . . . . . . . . . . . 23

3. Output and Investment Response to External Shock, Conditional on Short Term External Debt and Exchange Rate Regime . . . . . . . . . . . . . . 2 26

4. Output and Investment Response to External Shock, Conditional on Import Structure and Exchange Rate Regime . . . . . . . . . . . . . . . . . . . . 29

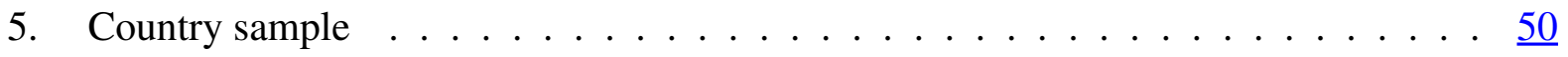

Figures

1. Output response to a negative external demand shock: Difference between float and peg. . . . . . . . . . . . . . . . . . 14

2. Kernel density of import structure and debt under float and peg . . . . . . . $\underline{19}$

3. Impulse Responses for an initial 10\% Terms of Trade Shock under LYS classification $\underline{22}$

4. Impulse Responses for a negative 10\% Terms of Trade Shock under LYS classifi-

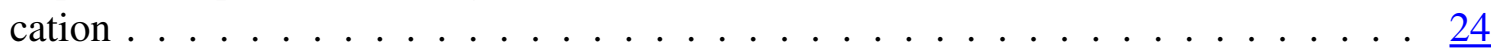

5. Cumulative Response of Output and Investment to a $10 \%$ ToT Shock in the second year as a function of foreign currency debt . . . . . . . . . . . 25

6. Impulse Responses for a Negative $10 \%$ Terms of Trade Shock under LYS classification . . . . . . . . . . . . . . . . . . . . . 27

7. Cumulative Response of Output and Investment to a $10 \%$ ToT Shock in the second year as a function of raw material share in total imports . . . . . . . . 28

8. Output response to a negative $10 \%$ terms of trade shock in the second year: Difference between float and peg. . . . . . . . . . . . . . . 30 


\section{INTRODUCTION}

Traditional arguments for flexible exchange rate regimes, as advanced by Friedman (1953) or Mundell (1961) and Fleming (1962), emphasize the expenditure switching effect. When a country faces an adverse real shock, a nominal depreciation can stabilize output by boosting net exports. Since then the theoretical literature has cast doubt on the effectiveness of flexible exchange rates to stabilize output when there is high foreign currency debt or limited exchange rate pass-through.

If a firm borrows in foreign currency, a depreciation increases its foreign currency debt reduces its profits and its net present value. A lower firm value makes banks more reluctant to lend and the tighter credit conditions lead to a drop in investment and output. The theoretical literature has not reached a clear verdict on whether the destabilizing effects of exchange rate fluctuations through balance sheets are strong enough to make output more responsive to external shocks under a float than under a peg. Céspedes, Chang, and Vélasco (2004), Devereux, Lane, and Xu (2006), and Gertler, Gilchrist, and Natalucci (2007) find that even with sizable foreign currency debt depreciations remain expansionary. Cook (2004) argues that the results depend on the source of stickiness. If, as in Céspedes, Chang, and Vélasco (2004), wages are sticky but prices are not, a depreciation is still expansionary because it lowers real wages and increases revenues. If prices are sticky and wages are not, we have the opposite case and a fixed exchange rate is preferable. Choi and Cook (2004) introduce a banking sector with domestic currency assets and foreign currency liabilities and find that fixed exchange rates perform better irrespective of the source of nominal rigidity. A related issue has arisen in the recent financial crisis as several countries' access to external finance sharply deteriorated and external demand fell. There is now an active debate whether a country with high foreign currency debt can shield its economy from such a negative external shock better under a floating or a fixed exchange rate. While an exchange rate depreciation may induce balance sheet effects, a constant exchange rate implies that a real depreciation must be achieved through wage or price disinflation, which may also be very costly. ${ }^{1}$

Expenditure switching effects are absent if there is no exchange rate pass-through. If there is pricing-to-market (Krugman, 1986) and imported goods are priced in domestic currency, an exchange rate depreciation cannot affect the price of imported goods and the relative price of domestic and imported goods remains unaltered. Despite the flexible exchange rate regime

\footnotetext{
${ }^{1}$ In a recent study, Tsangarides (2010) finds that the output response to the shock during the financial crises $2008 / 09$ of countries with a peg was comparable to countries that maintained floating exchange rate regimes.
} 
there is no expenditure switching effect, and monetary policy is less effective in stabilizing output (Devereux and Engel, 2003).

While the theoretical implications of limited exchange rate pass-through are less controversial than those of foreign currency debt, we are not aware of any empirical analysis linking passthrough to the buffer properties of different exchange rate regimes. The literature has focused primarily on the extent and determinants of exchange rate pass-through. Pricing-to-market requires some monopoly power. Homogeneous, simple, goods markets are more competitive. Since pricing-to-market is less prevalent in homogeneous good markets, pass-through should be higher. Campa and Goldberg (2005) show that for OECD countries pass-through in the raw material and energy sector is higher than in other sectors. ${ }^{2}$ They find that a large fraction of the observed decline in pass-through can be explained with a change in the import structure away from primary commodities. For a given demand elasticity, exchange rate movements should therefore have a larger effect on import demand in countries with a high share of homogeneous goods imports. Kohlscheen (2010) provides similar evidence for a sample of emerging countries. Our empirical analysis uses this result to investigate how import structure affects the insulation properties of floating exchange rates. ${ }^{3}$

The main contribution of this study is to addresses the controversy around the relevance of balance sheet effects empirically and to provide evidence on the role of import structure for the insulation properties of exchange rate regimes. We introduce an Interacted Panel Vector Autoregression (IPVAR) as a framework to test how country characteristics affect the response of the economy to shocks. Using a sample of 101 countries we estimate a Panel VAR and augment it with interaction terms that allow the VAR coefficients to vary with foreign currency debt and import structure. With this technique we can directly analyze how the responses of output and investment to external shocks vary with external debt, import structure and exchange rate regime. While researchers routinely use interaction terms in single equation empirics, studies that employ interaction terms in VARs are few. The use of interaction terms in Panel VARs is a simple way to allow for deterministically varying coefficients across time and countries. The framework thereby provides an alternative to the stochastically time-varying coefficient frameworks often employed in single country VARs. ${ }^{4}$

\footnotetext{
${ }^{2}$ Consistent with these findings, Engel (1993) finds empirically that the law of one price holds better for homogeneous goods.

${ }^{3}$ Another strand of the literature considers the extent of pass-through to be endogenous to monetary policy and therefore to the exchange rate regime (Taylor, 2000). Under this theory, firms adjust their optimal pricing strategy to the monetary policy regimes in place and more stable inflation increases the incentive to prices in domestic currency. Our analysis focuses on the effect of import structure and we detail this choice in Section III.

${ }^{4}$ Loayza and Raddatz (2007) are closest to our empirical approach, but only let the coefficients on exogenous variables vary and impose homogeneity on the dynamics of endogenous variables.
} 
Our results indicate that the insulating properties of flexible exchange rate regimes are strong in economies where the import share of high pass-through goods is large and foreign currency debt is low. With a small share of homogeneous imports and a high degree of foreign currency debt fixed exchange rates display better stabilization properties, as limited pass-through hinders the adjustment of relative prices under a float and contractionary balance sheet effects dominate.

The results stand in contrast to early empirical studies that found no effects of the exchange rate regime on output dynamics. For instance, Baxter and Stockman (1989) and Flood and Rose (1995) compared the unconditional volatility of macroeconomic variables under the Bretton Woods system of fixed exchange rates and under the post Bretton Woods system of floating exchange rates. They found little differences across the two periods, except for the well known fact that the real exchange rate is substantially more volatile under floating exchange rate regimes (Mussa, 1986). According to a study by Ghosh and others (1997) output volatility is lower under flexible regimes, whereas inflation volatility is higher. These studies, however, do not discriminate between real and nominal shocks, whereas MundellFleming logic suggests that fixed exchange rates are preferable if nominal disturbances dominate and flexible exchange rates are preferable if real disturbances dominate.

To identify real shocks, a series of studies take advantage of the fact that the rest of the world is virtually not affected by domestic conditions in small countries. For small economies a number of variables can therefore be treated as exogenous. Several authors compare the response of GDP to an exogenous variable under different exchange rate regimes in a single equation framework and generally find the exchange rate regime to matter. They find that under a flexible exchange rate regime the output growth rate is less sensitive to variations in the terms of trade (Edwards and Levy Yeyati, 2005), world interest rates (di Giovanni and Shambaugh, 2008), and natural disasters (Ramcharan, 2007).

A drawback of the single equation approach is that it does not look at the response to a true, unexpected, shock and its transmission, but at the sensitivity of output to contemporaneous values of a specific exogenous variable. Broda (2004) and Broda and Tille (2003) tackle this issue with a Panel VAR approach and treat the terms of trade as a block exogenous variable. They look at the response of real GDP to a terms of trade shock in a sample of developing countries and find that output responds stronger under a peg. Also within a Panel VAR framework, Hoffmann (2007) finds that flexible exchange rates insulate better from shocks to world output and world real interest rates. Miniane and Rogers (2007) provide evidence that the nominal interest rate in countries with fixed exchange rates responds more to U.S money 
shocks. None of the studies accounts for country characteristics apart from the monetary policy regime such as import structure and foreign currency debt.

To our knowledge there is no empirical study which analyzes the buffer properties of different exchange rate regimes to external shocks for varying levels of foreign currency debt. However, there is a literature that investigates the link between the effects of exchange rate depreciations and the level of foreign currency debt. ${ }^{5}$ Most of these studies find that depreciations tend to be contractionary when foreign currency debt is high (Bebczuk, Panizza, and Galindo, 2006; Cavallo and others, 2005; Galindo, Panizza, and Schiantarelli, 2003). These studies use exchange rate fluctuations as an explanatory variable, whereas we look at output responses conditional on an exogenous shock under different exchange rate regimes. We are not aware of any study that investigates the role of import structure for the adjustment to external shocks.

In the remainder Section II synthesizes the theoretical literature on the effects of foreign currency debt and import structure in a stylized microfounded three equation IS-LM-BP model, based on previous work by Céspedes, Chang, and Velasco (2003). Section III and IV explain the data and the estimation technique. Section V discusses the main results. Section VI concludes.

\section{THEORY}

To illustrate the effects of foreign currency debt and import structure, the microfounded ISLM-BP framework by Céspedes, Chang, and Velasco (2003) with sticky prices, wages, and a financial accelerator mechanism as in Bernanke, Gertler, and Gilchrist (1998), is extended along two dimensions. We introduce limited exchange rate pass-through by distinguishing between homogeneous import goods with prices set on the world market and heterogeneous import goods that are priced to the domestic market. Furthermore, to have a meaningful expenditure switching effect, we abandon the assumption of a unit elasticity of substitution between domestic and foreign goods. The model consists of a small open economy model with two periods (1 and 2), and two types of agents: workers and entrepreneurs. Goods prices and wages are set one period in advance. The model exhibits with limited exchange rate passthrough and the presence of foreign currency debt two key dimensions. The two key parame-

\footnotetext{
${ }^{5}$ Hausmann, Panizza, and Stein (2001) find that "fear of floating" occurs more often in countries with high foreign currency debt. Authorities limit exchange fluctuations, although they declare themselves officially as floaters. This can be interpreted as indirect evidence of the favorability of fixed exchange rate regimes under such circumstances.
} 
ters are given by the share of homogeneous goods in total imports $\omega$, and the share of foreign currency debt $\xi$.

Entrepreneurs finance the capital $Q_{1} K_{1}$ out of their net worth $P_{1} N_{1}$ and with debt. As in Bernanke, Gertler, and Gilchrist (1998) they pay a risk premium $\eta_{1}$ that increases with the share of debt.

$$
1+\eta_{1}=\left(\frac{Q_{1} K_{1}}{P_{1} N_{1}}\right)^{\mu}
$$

where $\mu$ capture the degree of financial imperfections. The entrepreneurs' nominal net worth $P_{1} N_{1}$ is nominal revenue $P_{1} Y_{1}$ net of wage payments $\left(W_{1} L_{1}\right)$ and debt repayment $\left(D_{1}^{T}\right)$.

$$
P_{1} N_{1}=P_{1} Y_{1}-W_{1} L_{1}-S_{1} \xi D_{1}^{T}-(1-\xi) D_{1}^{T}
$$

The larger the share of foreign currency debt, the larger is will be the effect of fluctuations in the exchange rate $S_{1}$ on net worth. The combination of a financial accelerator and foreign currency debt leads to balance sheet effects which make depreciations potentially contractionary.

Consumers consume home and foreign goods which are substitutable with elasticity $\phi$ and weights $\gamma$ and $1-\gamma$. Foreign goods in turn are a Cobb-Douglas bundle of homogeneous goods with share $\omega$ and heterogeneous goods with share $1-\omega$.

The expenditure minimizing price index of the consumption bundle is

$$
Q_{t}=\left[\gamma P_{H, t}^{1-\phi}+(1-\gamma)\left\{\left(P_{F, t}^{H O M}\right)^{\omega}\left(P_{F t}^{H E T}\right)^{1-\omega}\right\}^{1-\phi}\right]^{\frac{1}{1-\phi}}
$$

Homogeneous goods are priced on the world market in foreign currency, whereas domestic goods are priced to market in domestic currency. A higher the share of differentiated import goods implies more incomplete exchange rate pass-through, which in turn lowers the benefitial effect of depreciations on net exports due to limited expenditure switching.

The model can be reduced to a system of three (log linear) equations that correspond to the familiar IS-LM-BP model. The detailed derivations of the model are provided in the appendix. We use the log linear model to illustrate the response of output and investment to an adverse external demand shock under different exchange rate regimes. 


\section{A. IS-LM-BP with Foreign Debt and Incomplete Pass-through}

The IS equation which pins down the response of output $\left(y_{1}\right)$ is a function of investment $\left(i_{1}\right)$, foreign demand $\left(x_{1}\right)$, and the exchange rate $\left(s_{1}\right)$ change in period one and is given by:

$$
A y_{1}=\lambda i_{1}+(1-\lambda) x_{1}+[(1-\lambda)+\omega \cdot \lambda g(\phi)] s_{1}
$$

where $A$ is a positive constant. $\lambda<1$ is the steady state share of investment demand in domestic output net of consumption and, correspondingly, $(1-\lambda)$ is the share of exports. $g(\phi)$ is increasing in the substitution elasticity $(\phi)$ between domestic and foreign goods. A depreciation (an increase of $s$ ) affects domestic output through two channels. The first term in brackets $(1-\lambda)$ stands for the export revenue effect. A depreciation increases the amount of domestic currency output necessary to satisfy a given demand in foreign currency. The second term $(\omega \cdot \lambda g(\phi))$ captures the expenditure switching effect. The strength of the expenditure switching effect increases with the share of homogeneous goods $\omega$ and therefore the exchange rate pass-through. If the country imports only differentiated goods $\omega=0$, the expenditure switching channel is lost, since a depreciation cannot affect relative prices.

The BP curve pins down the demand for investment and is a function of the foreign interest rate $(\rho)$, output $\left(y_{1}\right)$ and the exchange rate $\left(s_{1}\right)$. It is given by:

$$
\Gamma i_{1}=-\rho+\mu(1+\psi) \delta_{y} y_{1}-\mu\left[\left(1-\gamma_{1}^{\prime}\right) \omega+\psi \xi\right] s_{1}+\left[1-\left(1-\gamma_{1}^{\prime}\right) \omega\right] s_{1}
$$

where the coefficients $\Gamma, \delta_{y}$ an $\gamma_{1}^{\prime}$ are positive. The investment demand is a function of the borrowing cost from abroad and depends on the risk premium, the risk free rate, and the price of investment. A higher world interest rate $\rho$ depresses investment. The effect of output on investment demand depends on the degree of financial imperfection $\mu$ and the ratio of total debt over net worth $\psi$. Higher output increases net worth, lowers the risk premium and raises investment. Higher leverage $\psi$ thus amplifies the effects of output on investment demand. Whether an exchange rate depreciation increases or decreases investment depends on the extent of financial imperfections and leverage. Without imperfections $(\mu=0)$ a depreciation always increases investment since it decreases the domestic real risk free rate through an increase in anticipated inflation (real risk free rate effect). The expansionary effects that derive from the lower real risk free rate $\left(\left[1-\left(1-\gamma_{1}^{\prime}\right) \omega\right]\right)$ can be overturned by contractionary balance sheet effects $\left(-\mu\left[\left(1-\gamma_{1}^{\prime}\right) \omega+\psi \xi\right]\right)$. A depreciation can be contractionary because it increases the ratio of nominal investment to net worth. First, a depreciation increases the price of investment, which increases the numerator of the ratio (investment cost effect). Second, it 
increases the domestic currency value of foreign currency debt which decreases the denominator (debt effect). The strength of the effect on net worth depends on firms' leverage $\psi$ and the share of foreign currency debt $\xi$. The contractionary effects that derive from financial imperfections dominate if financial frictions $\mu$, leverage $\psi$ and the share of foreign currency debt $\xi$ are high. ${ }^{6}$

Finally, we need to specify a monetary policy rule to close the model. We consider two regimes: a peg and a float. The peg is given by a no change policy for the exchange rate, i.e.:

$$
s_{1}=0
$$

While there is a unique way to model a peg, there is an infinite number of monetary policy regimes that can be considered as floats. We model the float as an exchange rate rule that lets the exchange rate appreciate if the economy contracts.

$$
s_{1}=-\kappa y_{1}
$$

The specification is not necessarily to be understood as some form of "dirty float"', but rather as a reduced form specification for a broad class monetary policies that let the exchange rate depreciate in response to adverse shocks (for example, by lowering the interest rate). ${ }^{7}$

\section{B. Adjustment to an External Demand Shock}

We use the described three equation framework to illustrate the theoretical adjustment to an external demand shock $\left(x_{1}\right)$. Results for a world interest rate shock $(\rho)$ are similar and not discussed for brevity. The proofs to all the results are provided in the appendix.

\footnotetext{
${ }^{6}$ While limited pass through diminishes expenditure switching in the IS curve, it also makes the effect of a depreciation on investment in the BP curve more positive, because it limits the increase in prices. The limited increase in prices reduces the contractionary investment cost effect and increases the expansionary real risk free rate effect. If foreign currency debt is large, the effect of limited pass-through on the price of investment in the BP curve is less important and the effect of diminished expenditure switching in the IS curve dominates.

${ }^{7}$ In the appendix we consider an alternative specification that aims for a stable money supply in the short run and a stable price level in the medium run and show that this policy can be replicated by the exchange rate rule with an appropriately chosen $\kappa=\kappa(\xi, \omega)$.
} 


\section{The Peg}

Under a peg the impact of an external demand shock on output and investment is determined by combining (1), (2) and (3), and taking the derivative of output with respect to external demand.

Result 1: The response of output and investment to an external demand shock is independent of the import share of differentiated goods and the level of foreign currency debt, since the exchange rate does not move under a peg.

The strength of the response of output increases with leverage $\psi$, as it amplifies the balance sheet effect related to a fall in output.

Result 2: The investment response is a multiple of the the output response and increases with leverage and the level of financial imperfection.

With no imperfection investment does not respond, since financing costs do not move.

\section{The Float}

To derive the impact on output under a float, we combine the IS and BP equation (1), (2) with the rule under the float (4). The effect of the external shock on output can be split in five components. The first effect is identical to the peg. The second effect reflects the expenditure switching effect and is expansionary. It is increasing in the elasticity of substitution. The third effect reflects the export value effect which is increasing in the export share. Finally, there are two opposing effects on the cost of financing investments. On the one hand, a depreciation causes the real risk free rate to fall, making investment less costly. However, on the other hand in the presence of financial imperfections, a depreciation can cause a contraction. A deprecation increases the ratio of investment over net worth by increasing the price of investment and reducing net worth due to an increased debt burden. This effect is the balance sheet effect which is related to the share of foreign debt.

Result 3: The ability of a float to stabilize output diminishes as the share of homogeneous import goods declines and the level of foreign currency debt increases. 


\begin{tabular}{cccccc}
\hline & \multicolumn{2}{c}{ foreign currency debt } & & \multicolumn{2}{c}{ import structure } \\
\cline { 2 - 3 } \cline { 5 - 6 } & $\frac{\partial y}{\partial x \partial \xi}$ & $\frac{\partial i}{\partial x \partial \xi}$ & & $\frac{\partial y}{\partial x \partial \omega}$ & $\frac{\partial i}{\partial x \partial \omega}$ \\
\hline Peg & $=0$ & $=0$ & & $=0$ & $=0$ \\
Float & $>0$ & $>0$ & & $<0$ & $<?>0$ \\
\hline
\end{tabular}

Table 1. Summary of Theoretical Predictions

We can calculate the threshold for which such a policy becomes actually more destabilizing than a peg.

Result 4: An economy reaches the threshold foreign currency debt share more quickly if exchange rate pass-through is low, such that the expenditure switching effects are small, and leverage and financial imperfections are strong. Thus there are relevant interactions which affect the buffer properties of a float.

Similar to the effect on output the effect on investment can be decomposed into three main effects. The first effect captures the impact on net worth and the external finance premium caused by a drop in output. As output falls due to lower demand, the net worth falls and the the risk premium increases, reducing the demand for investment. The second effect captures the additional effects that come from exchange rate changes. A depreciation increases the risk premium, both via increasing the price of investment and by increasing the domestic currency value of foreign debt. The third part captures the only positive effect due to the lowered domestic real risk free rate which is brought about by a depreciation. This effect is independent of the level of financial frictions.

Result 5: A higher share of foreign currency debt increases the response of investment.

Result 6: The effect of the import structure is ambiguous, because limited pass-through moderates the effect on prices, but increases the effect on output. With high leverage the effect on output dominates.

Table 1 summarizes the predicted effects of foreign currency debt and import structure for the responses of output and investment to external shocks under the two exchange rate regimes. 


\section{Simulation of Responses under Peg and Float}

To illustrate graphically how the response of investment and output change with the ratio of foreign currency debt and the share of homogeneous goods in total imports, we let the parameters $\xi$ and $\omega$ vary for given values of the other parameters. We assume values which are standard in the literature. In particular, the share of home goods in total consumption is assumed to be $\gamma=0.6$, the mark-up for differentiated products $10 \%(\theta=11)$ and, the elasticity of substitution between foreign and home consumption goods is assumed to equal $\phi=2$. The capital market imperfection is set to $\mu=0.2$ as in Céspedes, Chang, and Velasco (2003). We set $\kappa=2$ and $\beta=0.96 .{ }^{8} \bar{K}_{1}, \bar{X}_{1}, \bar{X}_{2}$ are such that output growth $\frac{\bar{Y}_{2}}{\bar{Y}_{1}}$ and the real exchange

rate in both periods $\frac{\bar{S}_{1}}{\bar{P}_{1}}$ and $\frac{\bar{S}_{2}}{\bar{P}_{2}}$ are one. We choose $\psi=10.6$ such that ratio of external debt to GDP equals $36 \%$. The value corresponds to the midpoint between the average short term external debt and the total external debt in our sample of countries. ${ }^{9}$ Using these parameter values we allow the share of homogeneous good imports to vary from close to zero to $50 \%$ and the foreign currency debt to GDP ratio from zero to $36 \%$, holding the overall debt level constant. ${ }^{10}$ Figure 1 depicts the joint role of foreign currency debt and import structure. It shows the difference in the fall of output to a negative external demand shock between a country with a float and a country with a peg $\left(\left.\frac{\partial y}{\partial x}\right|^{F L}-\left.\frac{\partial y}{\partial x}\right|^{P E G}\right)$. The response under a peg is smaller if foreign currency debt is high and the share of homogeneous goods is low.

\section{DATA}

We analyze the role of foreign currency debt and the import structure using a sample which covers yearly data for 101 countries from 1974-2007. We impose the following restrictions on the data: the sample does not include G7 countries, as the identifying assumption on the exogeneity of external shocks may not hold for large countries. Because of data quality concerns the study uses only countries for which we have more than five data points and discard very poor countries with a PPP adjusted GDP per capita of less than 1000 dollars in 2007. We drop small countries with a population of less than 1 million and observations where the annual change in real GDP exceeds twenty percent. In line with previous studies we only

\footnotetext{
${ }^{8}$ Increasing $\kappa$ lets the shape of the exchange rate response become increasingly concave.

${ }^{9}$ In the empirical part we will be using these measures alternatively.

${ }^{10}$ There is a direct link in the model between the share of foreign debt to GDP and the parameter $\xi$ which is derived in the appendix.
} 


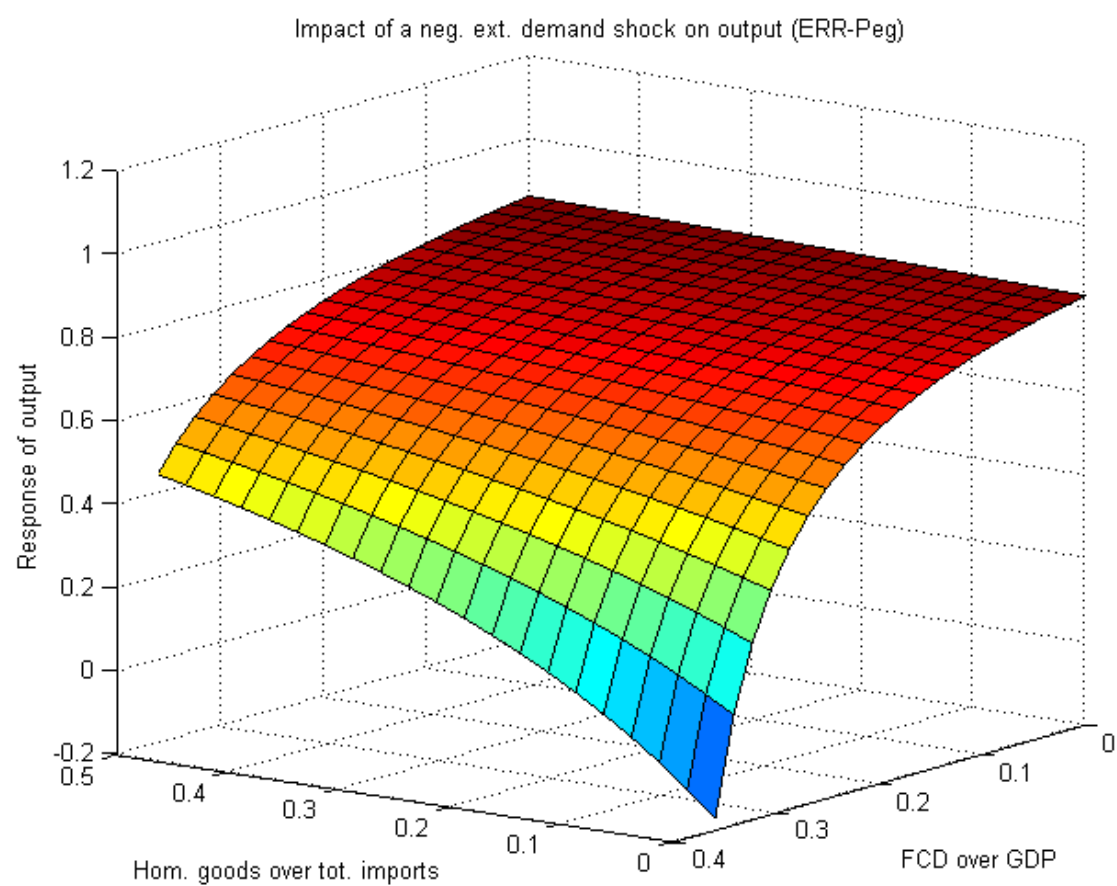

Figure 1. Output response to a negative external demand shock: Difference between float and peg.

consider observations where inflation was reasonably low (below fifty percent). Furthermore, we restrict the exchange rate regime to be in place at least one period, to avoid crosscontamination due to exchange rate regime transitions. Data come from various sources including the IMF's International Financial Statistics (IFS), the World Bank's World Development Indicators (WDI) and the Bank of International Settlements (BIS). For a detailed description see the appendix.

(a) Foreign Debt We employ three alternative measures. The first measure is short term external debt over GNI provided by the WDI. We prefer short term debt over total debt, since there is less of a roll over problem for long term debt and balance sheet effects are less immediate. As a robustness check we also report results for total external debt. Both measures do not cover industrial countries. It is possible that part of the external debt is in domestic currency, but according to Lane and Shambaugh (2010)'s dataset almost hundred percent of external debt (as opposed to total external liabilities) is in foreign currency. As an alternative measure we use the claims on the domestic economy by foreign banks scaled by GDP from the BIS. The disadvantage of this dataset is that it starts only in 1983 and only covers claims 
of banks from reporting countries. To reduce sensitivity to outliers we use $\log (1+d e b t)$, where debt is the corresponding debt measure expressed in percentage points. ${ }^{11}$

(b) Import Structure In line with findings by Campa and Goldberg (2005) we use the share of primary commodities in a country's total imports of goods and services to measure the extent to which a country imports high pass-through goods. The share of primary commodities in total imports is proxied by the sum of agricultural goods, fuels, ores and metals over total imports as provided by the WDI. Again we use $\log (1+i m p)$, where imp is the import share of raw material in percentage points. ${ }^{12}$ The raw material share is an indirect measure for import price pass-through. We see several advantages over the use of a direct measure. First, there are, to our knowledge, no direct import pass-through measures available for our broad sample of countries. Estimating them would be a task of its own and would also ask for a high degree of data quality and availability. Second, the literature has identified two factors that affect import price pass-through: the sectoral structure and monetary policy. Monetary policy is at least partially accounted for by our exchange rate regime variable and from a policy perspective it makes sense to evaluate the effects of the parts of exchange rate pass-through that are orthogonal to monetary policy separately. A further argument in favor of our measure is that pass-through varies not only over countries, but also over time. Country by country pass-through estimates would be constant. In fact, the cross sectional mean of our measure varies between $23 \%$ in 1981 and $11 \%$ in 1999. Apart from the advantages discussed above, a potential disadvantage of using the raw material share as a pass-through measure is that a high raw material share might also have other effets than higher import price pass-through. As detailed below, our empirical application will allow to separate the effect a higher raw material has independent from the exchange rate regime from the effect that is conditional on the exchange rate regime.

(c) Exchange Rate Regime The literature divides between de jure classification and de facto classification. According to Ghosh, Gulde, and Wolf (2002) the de jure classification may be understood as the intention of the authority, while the de facto classifications attempts to capture the actual behavior of the respective authority. Since we are interested in the actual

\footnotetext{
${ }^{11}$ We do not distinguish public and private debt. While accurate data of comparable coverage is not easily available, using overall debt as opposed to private debt, is likely to work against finding balance sheet effects.

${ }^{12}$ In our analysis we focus on import prices because exchange policy can affect exports both if export prices are set in domestic or in foreign currency. If they are set in domestic currency a nominal depreciation makes them cheaper in foreign currency. The depreciation then leads to an increase in export demand and a rise in export volume. If prices are set in foreign currency a depreciation leads to an increase in the domestic currency value of exports, while the export volume is constant.
} 
conduct of exchange rate policy, our preferred exchange range classification is Levy-Yeyati and Sturzenegger (2005)'s de facto classification (LYS) which covers the period from 1974 to 2004. The authors use cluster analysis on exchange rate data and official reserves to infer the actual exchange rate policy. The classification has the advantage that it does not rely on the movements of the exchange rate alone. A country may be pursuing inflation targeting under a freely floating exchange rate, but the observed path of the exchange rate may be quite stable because of the stability of underlying fundamentals. A classification which uniquely relies on the movement of the exchange rate would incorrectly label this country as maintaining a (soft) peg. To remain consistent and comparable with most of the literature (see, for example, Broda, 2004; di Giovanni and Shambaugh, 2008), we use an exchange rate dummy that takes the value one for a peg and zero for non peg. This approach is also in line with the theoretical framework, where we distinguish between a monetary policy that keeps the nominal exchange rate constant and a policy that lets the exchange rate vary to some degree. We will compare our results with estimates using the IMF's de jure classification (1974-2007).

(d) Terms of Trade We derive our terms of trade measure from various sources. The choice of the source is guided by the length of the provided series. For most developed countries we use the IFS terms of trade, since it is available for a long enough period. For other nations we use UNCTAD's terms of trade measure. If also the latter was not available for a long enough period, we made use of the constant and current export and import values available from the WDI to construct the implied terms of trade. ${ }^{13}$ For a detailed description and the respective measures employed see the appendix.

(e) Foreign Interest Rate To measure the real foreign interest rate we use the short term real interest rate of the reference country of relevance. The reference country is defined as in di Giovanni and Shambaugh (2008), essentially being the country by which a home country's monetary policy is influenced. ${ }^{14}$ Depending on availability, the nominal short term rate is given by the money market or treasury bill rate and the real rate is obtained by subtracting CPI inflation from the nominal rate in the reference country.

(f) National Accounts Real GDP and investment in local currency are taken from the WDI.

\footnotetext{
${ }^{13}$ Apart from few exceptions, if various measures exist, they tend to be identical or highly correlated.

${ }^{14}$ The original dataset is somewhat shorter than our sample. For missing countries we used the updated information provided by Reinhart and Rogoff (2004) on the partner country
} 


\section{MOdEL AND ESTIMATION}

\section{A. Empirical Model and Identification}

In order to examine the conditional response to external shocks we estimate a recursive Interacted Panel VAR of the form:

$$
\left(\begin{array}{ccc}
1 & 0 & 0 \\
\alpha_{0, i t}^{21} & 1 & 0 \\
\alpha_{0, i t}^{31} & \alpha_{0, i t}^{32} & 1
\end{array}\right)\left(\begin{array}{c}
\Delta E X V_{i t} \\
\Delta I N V_{i t} \\
\Delta G D P_{i t}
\end{array}\right)=\mu_{i}+\sum_{l=1}^{L}\left(\begin{array}{ccc}
\alpha_{l}^{11} & 0 & 0 \\
\alpha_{l, i t}^{21} & \alpha_{l, i t}^{22} & \alpha_{l, i t}^{23} \\
\alpha_{l, i t}^{31} & \alpha_{l, i t}^{32} & \alpha_{l, i t}^{33}
\end{array}\right)\left(\begin{array}{c}
\Delta E X V_{i, t-l} \\
\Delta I N V_{i, t-l} \\
\Delta G D P_{i, t-l}
\end{array}\right)+U_{i t}
$$

where $E X V_{i, t}$ is an external variable, either the log terms of trade or the foreign real interest rate, $G D P_{i, t}$ is $\log$ real GDP, and $I N V_{i, t}$ is $\log$ real investment for country $i$ in period $t . U_{i, t}$ is a vector of uncorrelated iid shocks, $\mu_{i}$ is a vector of country specific intercepts and $L$ is the number of lags. $\alpha_{l, i t}^{j k}$ are deterministically varying coefficients.

We identify external shocks with a small open economy assumption. Small economies' actions have a negligible impact on goods' world prices and the foreign interest rate. The assumption implies that our two external variables do not depend on domestic conditions and implies therefore strict exogeneity, which amounts to $\alpha_{l, i t}^{12}=\alpha_{l, i t}^{13}=0$ for all $l$. Various other authors found that the exogeneity assumption for terms of trade generally holds for developing countries (Broda, 2004; Loayza and Raddatz, 2007; Raddatz, 2007). Since we are only interested in the identification of the shock to the external variable, the described partial identification scheme is sufficient and the ordering of GDP and investment does not matter. ${ }^{15}$

Our analysis focuses on the response of output and investment to real external shocks, but does not attempt to identify domestic real shocks. There are several reasons for this choice. First, external shocks can be an important source of fluctuation in many developing economies (Mendoza, 1995; Raddatz, 2007). Second, it improves comparability with the other studies that have also focused on real external shocks. Third, identification of external shocks is relatively simple for small open economies. Identification relies on the exogeneity of external variables, which has been shown to hold in various analyses of a similar type. It also does not impose high demands on detailed domestic data, which allows to assemble a relatively large data set across countries and time. While we focus on real external shocks, the discussed theory would suggest that our result should also hold for other real shocks for which identification is more involved.

\footnotetext{
${ }^{15}$ Under the strict exogeneity assumption the model can equivalently be written in VARX form $Y_{t}=$ $\sum_{l=1}^{L} C_{l} Y_{t-l}+\sum_{l=0}^{L} D_{l} \Delta E X V_{t-1}+E_{t}$ and $\Delta E X V_{t}=\sum_{l=1}^{L} F_{l} \Delta E X V_{t-l}+V_{t}$, where $Y_{t}=\left(I N V_{i, t}, G D P_{i, t}\right)^{\prime}$ and $V_{t}, E_{t}$ are error terms.
} 


\section{B. Interaction Terms}

In order to analyze how responses vary with country characteristics, we allow for interaction terms, such that the coefficients in (5) are given by:

$$
\begin{aligned}
\alpha_{l, i t}^{j k} & =\beta_{l, 1}^{j k}+\beta_{l, 2}^{j k} \cdot P E G_{i t}+\beta_{l, 3}^{j k} \cdot F C D_{i t}+\beta_{l, 4}^{j k} \cdot R A W_{i t} \\
& +\beta_{l, 5}^{j k} \cdot F C D_{i t} \cdot P E G_{i t}+\beta_{l, 6}^{j k} \cdot R A W_{i t} \cdot P E G_{i t}
\end{aligned}
$$

where $P E G_{i t}$ is the exchange rate regime dummy, $F C D_{i t}$ is the foreign currency debt measure and $R A W_{i t}$ is the share of raw materials. Several authors (Rogoff and others (2004) and Schneider and Tornell (2004)) have argued that there is a link between the exchange rate regime and the extent of foreign currency debt. ${ }^{16}$ Similarly, it is possible that there is link between the import structure and the exchange rate regime. Since the the interactions of exchange rate regime, import structure, and foreign currency debt all enter separately as explanatory variables, a correlation of these variables does not pose a problem to the approach. In addition, by also allowing explicitly for interactions between the exchange rate regime and the other two country characteristics, we can disentangle the individual effect of the respective variable and avoid capturing potential correlations. Empirically, however, we find no evidence for a link between the exchange rate regime and the level of debt or the import structure. Figure 2 compares the distribution of foreign currency debt and import structure across exchange rate regime using kernel density estimators. The distributions appear roughly comparable.

Previous studies that investigate stabilization properties of exchange rate regimes have set $\beta_{l, 3}^{j k}=\beta_{l, 4}^{j k}=\beta_{l, 5}^{j k}=\beta_{l, 6}^{j k}=0$. We start with the results for this specification for comparison purposes. We then look at the effects of import structure and foreign currency debt separately by either setting $\beta_{l, 3}^{j k}=\beta_{l, 5}^{j k}=0$ or $\beta_{l, 4}^{j k}=\beta_{l, 6}^{j k}=0$. Finally, we look at the most general case in which all coefficients are unrestricted. While we allow the coefficients to vary with country characteristics for output and investment, we restrict the external dynamics to be independent of country characteristics, i.e. $\alpha_{l}^{11}=\beta_{l, 1}^{11}$ for all $l$. A Wald test does not reject the null hypothesis and confirms the appropriateness of the assumption. As in every VAR single coefficients $\alpha_{l, i t}^{j k}$ cannot be interpreted. We can, however, evaluate the coefficients at specific values and then compute impulse responses. ${ }^{17}$ While the exchange rate regime is a dummy variable,

\footnotetext{
${ }^{16}$ However, Arteta (2005) finds an opposite pattern.

${ }^{17}$ Loayza and Raddatz (2007) apply a similar technique, but let only the coefficients on the external variable coefficients vary with country characteristics. The procedures leaves more degrees of freedom, but assumes that there is only heterogeneity in the initial response, but not in the transmission. The authors find that less flexible
} 

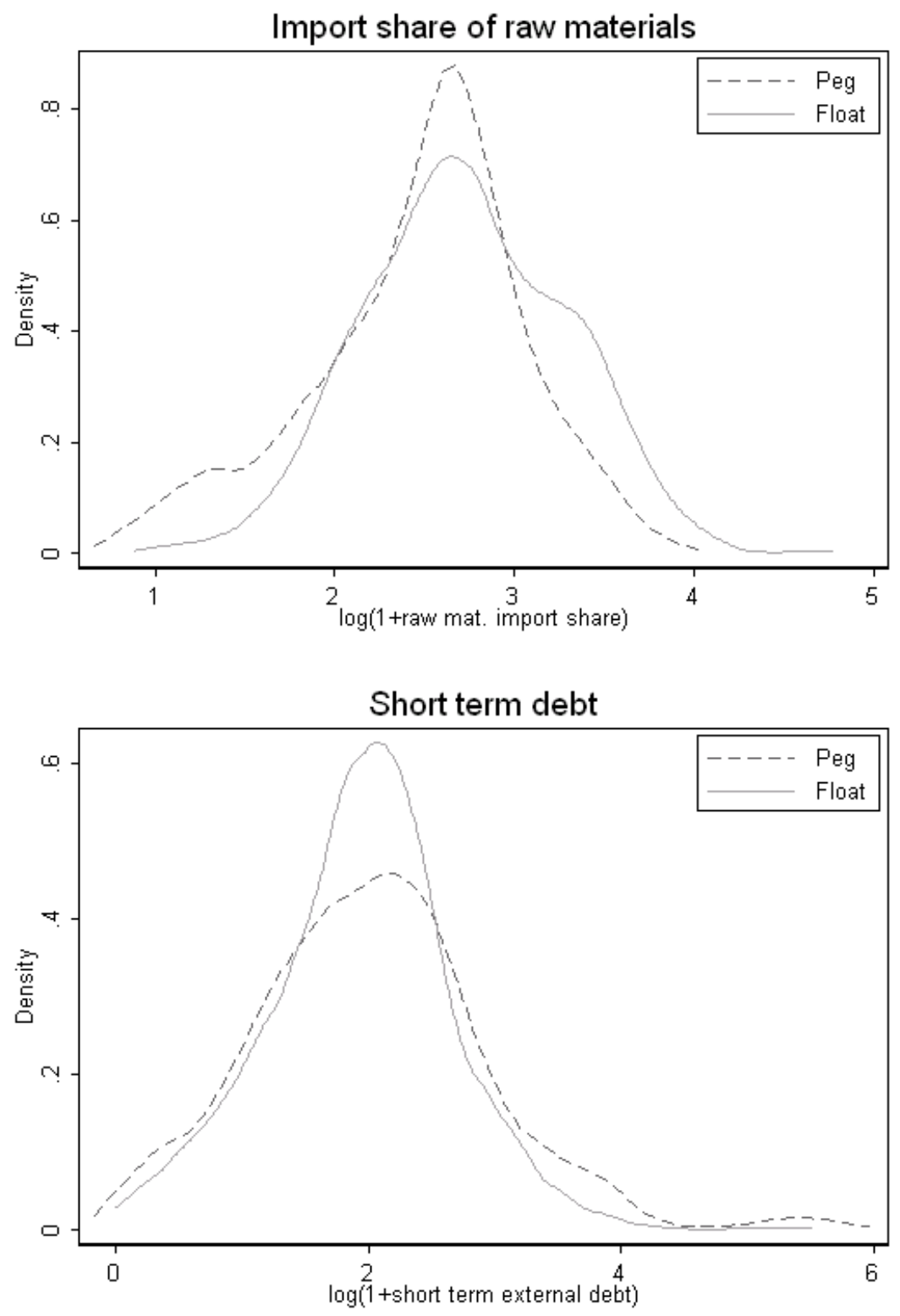

Figure 2. Kernel density of import structure and debt under float and peg

our measures of foreign currency debt and raw material share are defined over a continuous range. As a benchmark we evaluate continuous variables at a lower (20th) percentile and a higher (80th) percentile value. ${ }^{18}$ For the exchange rate dummy the evaluation are taken at one

labor markets and higher trade openness increase the response of a country's GDP to terms of trade shocks.

${ }^{18}$ Alternatively, we can generate a dummy based on the division of country observations with high and low external debt level and high and low raw materials share. While the continuous indicator imposes that the response changes in a $(\log )$ linear manner with the indicator value, the dummy implies a threshold effect relationship. Results with dummies (not presented) underpin our findings. 
(peg) and zero (float).

\section{Estimation and Inference}

We estimate the Panel VAR using OLS and allow for country fixed effects Since the error terms are uncorrelated across equations by construction, we can estimate (5) equation by equation without loss in efficiency. We choose two lags following the Schwartz Criterion. ${ }^{19}$

Pesaran and Smith (1995) have shown that if there is heterogeneity in the slope coefficients across countries, estimates that impose a common slope are biased. The authors propose a mean group estimator. However, using Monte Carlo simulations, Rebucci (2003) shows that in typical macro panels fixed effects panel VAR estimators outperform mean group estimators unless slope heterogeneity is considerable. The reason is that the small sample bias may be more detrimental to the mean group estimator than the slope heterogeneity bias to the fixed effects estimator. Additionally, we are allowing slope coefficients to differ with country characteristics through the interaction terms. The use of interaction terms should therefore alleviate the bias from slope heterogeneity.

Since the impulse responses are a non linear function of the OLS estimates, analytical standard errors that rely on first order asymptotics may be inaccurate. To address this issue we use bootstrapped standard errors as proposed by Runkle (1987) adjusted for the fact that we are dealing with a Panel and make use of interaction terms. ${ }^{20}$ The procedure may be described in the following way. 1) Estimate (5) by OLS 2) Draw errors $\hat{\varepsilon}_{i, \tilde{t}}$ from a normal distribution $N(0, \hat{\Sigma})$ where $\hat{\Sigma}$ is the estimated covariance matrix 3$)$ use $\hat{\varepsilon}_{i, \tilde{t}}$ and the initial observations of the sample and the estimates of $\hat{\alpha}_{l, i t}^{j k}$ to simulate recursively $\hat{Y}_{i, 1}{ }^{21}$ 4) After the first period is simulated for all variables in the system interact the variables with the interaction terms and now repeat 2 and 3 as many times as there are errors. ${ }^{22} 5$ ) The artificial sample, together with the interaction variables, is then used to re-estimate the coefficients of (5) and (cumulative)

\footnotetext{
${ }^{19}$ In the presence of fixed effects and lagged dependent variables, IV (or GMM) estimators are preferable from an asymptotic point of view if $N$ is large and $T$ is small. Fixed estimates are consistent for a large $T$.

${ }^{20} \mathrm{The}$ programs to perform the estimation method as well as the programs to generate impulse responses and bootstrapped confidence intervals are available from the authors upon request.

${ }^{21}$ Different to the original procedure which was not described for the Panel VAR context, we draw initial observations panel specific and perform the simulation for each country.

${ }^{22}$ We simulated the response for each country over the entire sample length and eliminated at the end of the simulation those observations that where missing in the original sample to maintain the same weight for each country as in the initial data. Since the procedure requires the multiplication of the newly generated data with the interaction terms in the respective period, missing observations need to be filled by interpolation. These observations will however not be part of the newly generated data as explained above.
} 
IRFs are computed. 6) The procedure (step 2 to 5) is repeated 500 times. The $90 \%$ confidence interval is drawn from the simulated estimates.

We test in two ways whether interactions with exchange rate regime, foreign currency debt, or raw material share have a statistically significant effect on the dynamics of the variables. The first way, as for example done by Broda (2004), is to check with a Wald test whether the interaction terms in the recursive VAR model are jointly significant. We test separately for the joint significance of all interaction terms, the significance of all interaction terms involving $F C D$ or $R A W$ and the significance of all interactions between $P E G$ and FCD or RAW. Such a procedure tests whether the interaction terms can explain a statistically significant fraction of the overall variation in the dependent variables. The test allows no direct inference on whether there are significant differences in the response to a specific shock, at a specific time horizon. To address this question we look directly at the empirical distribution of impulse response differences and evaluate which fraction lies above zero. The bootstrap procedure automatically accounts for cross correlation between the impulse responses. We report the difference between pegs and floats, conditional on the level of foreign currency debt or import structure. We also bootstrap the difference in the peg-float difference between high and low foreign currency debt or high and low raw material share. We thereby account for the effect that import structure and foreign currency debt have irrespective of the exchange rate regime.

\section{RESUlts}

\section{A. Floats versus Pegs}

As a first step we contrast the response of output and investment under different exchange rate regimes, irrespective of the degree of foreign currency debt and of the import structure. Figure 3 shows the cumulative response of output and investment to a negative $10 \%$ terms of trade shock using the LYS exchange rate classification. With a peg output falls by about $0.9 \%$ after two years, whereas under a float output falls by about $0.5 \%$. The result is therefore in line with the classic argument that flexible exchange rates are better suited to absorb

real shocks and confirms previous empirical studies by Edwards and Levy Yeyati (2005) and Broda (2004). As shown in Table 2 the interaction terms are jointly significant according to a Wald test.The difference between the two output responses is marginally statistically significant. The responses of investment are similar and not statistically significantly different. 

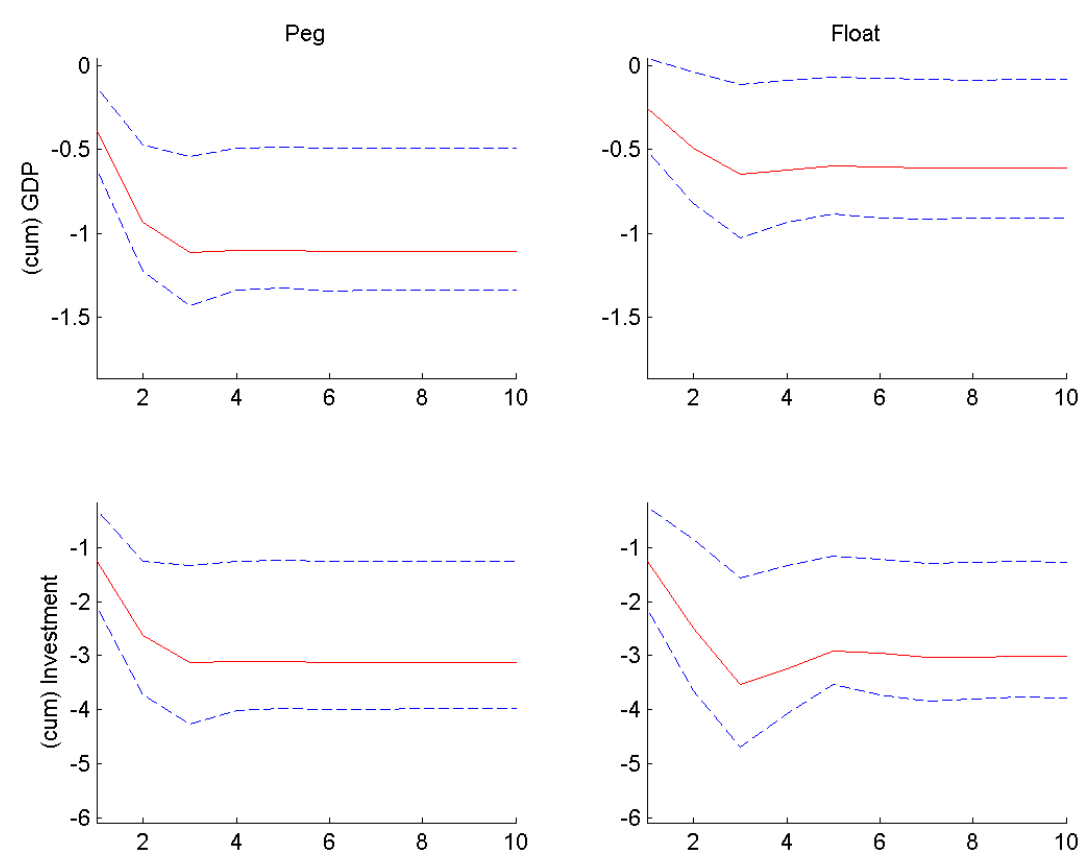

Figure 3. Impulse Responses for an initial 10\% Terms of Trade Shock under LYS classification

Table 2 presents the results for alternative specifications. With the IMF's de jure exchange rate regime classification, we again find evidence that the output response under a float is smaller. The results for a shock to the foreign interest rate are similar to those for the terms of trade shock. After a 100 bps shock output falls by about $0.2 \%$ under a peg after two years, whereas output under a float remains virtually unchanged.

\section{B. The Role of Foreign Currency Debt}

We proceed by looking at the response of output under different exchange rate regimes conditional on the degree of foreign currency indebtedness (Figure 4). Flexible exchange rates insulate better from terms of trade shocks if foreign debt is low: In the second year the output response under a flexible exchange rate is insignificant, while output has declined by more than one percent under a fixed exchange rate. The finding is reversed for high foreign debt: Under a peg the output response is of similar magnitude as under the low debt counterpart. The response under a float, however, is substantially stronger than in the low debt case and output declines by more than one percent. A Wald test confirms the joint significance of all interaction terms (Table 3). Pairwise output response comparisons indicate a significant dif- 


\begin{tabular}{|c|c|c|c|}
\hline & PEG & FLOAT & Difference \\
\hline \multicolumn{4}{|c|}{$\begin{array}{l}10 \% \text { Tot Shock, LYS } \\
\text { output }\end{array}$} \\
\hline 1st year & $-0.39^{* * *}$ & $-0.25^{*}$ & -0.14 \\
\hline 2nd year & $-0.93^{* * *}$ & $-0.49^{* *}$ & $-0.44^{*}$ \\
\hline $\begin{array}{l}\text { 5th year } \\
\text { investment }\end{array}$ & $-1.10^{* * *}$ & $-0.60^{* *}$ & $-0.50^{*}$ \\
\hline 1st year & $-1.25^{* * *}$ & $-1.24^{* * *}$ & -0.01 \\
\hline 2nd year & $-2.63^{* * *}$ & $-2.50^{* * *}$ & -0.14 \\
\hline 5th year & $-3.10^{* * *}$ & $-2.92^{* * *}$ & -0.18 \\
\hline Wald Test & 0.03 & & \\
\hline \multicolumn{4}{|c|}{$\begin{array}{l}10 \% \text { Tot Shock, IMF } \\
\text { output }\end{array}$} \\
\hline 1st year & $-0.25^{* *}$ & -0.05 & $-0.20^{*}$ \\
\hline 2nd year & $-0.69^{* * *}$ & $-0.28^{* *}$ & $-0.41^{*}$ \\
\hline $\begin{array}{l}\text { 5th year } \\
\text { investment }\end{array}$ & $-1.07^{* * *}$ & $-0.38^{* *}$ & $-0.69^{* * *}$ \\
\hline 1st year & $-1.45^{* * *}$ & 0.16 & $-1.61^{* * *}$ \\
\hline 2nd year & $-2.88^{* * *}$ & -0.31 & $-2.57^{* * *}$ \\
\hline 5th year & $-3.94^{* * *}$ & -0.75 & $-3.20^{* * *}$ \\
\hline Wald Test & 0.00 & & \\
\hline
\end{tabular}

100bps foreign interest rate shock, LYS

output

1st year $\quad 0.00 \quad 0.11 \quad-0.10$

2nd year $\quad-0.22^{*} \quad 0.04 \quad-0.26^{*}$

5th year $-0.38^{* * *}-0.05-0.33^{*}$

investment

$\begin{array}{llll}\text { 1st year } & 0.05 & 0.49^{*} & -0.44\end{array}$

2nd year $\quad-0.58 \quad-0.25 \quad-0.33$

5th year $-1.54^{* * *}-0.68 \quad-0.86$

Wald Test 0.01

${ }^{*, * \star *, * *}$ indicate that zero lies outside the

$68 \%, 90 \%$, 95\% confidence bands

Table 2. Output and Investment Response to External Shock, Conditional on the Exchange Rate Regime

ference between pegs and floats when foreign currency debt is low, but not if it is high. We also find that the change in the difference is statistically significant when moving from low to high foreign currency debt. The balance sheet effects theory suggests that the main reason for the difference between the output response of a float with high and low foreign currency debt is investment. With high foreign currency debt, a depreciation reduces firm's net worth more, 
which leads to tighter credit conditions and less investment. Figure 4 affirms the importance of investment, although the confidence bands are rather wide. With low foreign currency debt, investment behaves similarly under both exchange rate regimes. It declines by about 1.7 percent under a peg and one percent under a float within two years. With high foreign currency debt, the investment response under a float is stronger: investment declines by 4.5 percent under a float compared to 2.8 percent under a peg.
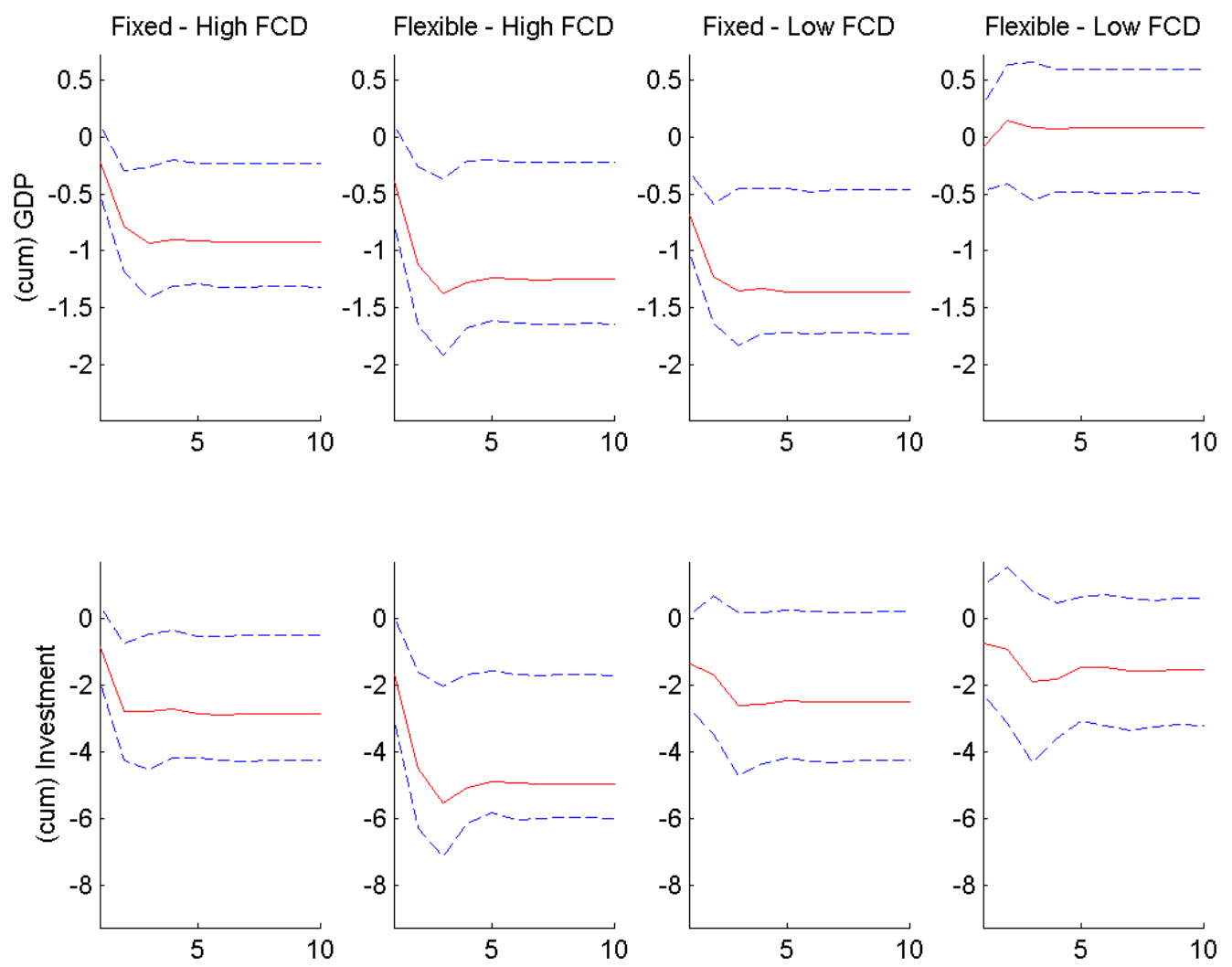

Figure 4. Impulse Responses for a negative 10\% Terms of Trade Shock under LYS classification

With the estimates at hand, we can simulate the accumulated response of output to terms of trade shocks across various degrees of external indebtedness and define zones for which floats insulate output better from terms of trade shocks than pegs. Figure 5 shows the accumulated response of output after two years for varying degrees of indebtedness. ${ }^{23}$ The response of output to the shock under fixed regimes shows no particular sensitivity to the extent of for-

\footnotetext{
${ }^{23}$ The conclusion is similar if we use other horizons.
} 
eign currency debt, but under a float the response rises with higher debt. According to the estimates output responds less under a float up to a short term external debt to GNI ratio of 10 percent. Roughly 25 percent of all observations lie above this threshold. The investment response under a float is stronger for most levels of foreign currency debt and increases also faster with debt compared to a peg. The higher sensitivity of investment under a float is consistent with the idea that balance sheet effects play an important role. Table 3 reports alternative specifications. Our results for output and investment with total external debt instead of short term debt are quantitatively similar, but display higher parameter uncertainty. Using claims of foreign banks as reported by the BIS instead gives again similar results. Using the IMF's de jure exchange rate regime classification also confirms our findings. The results for responses to a foreign interest rate shock are a bit less clear. Both with high and low debt, the output response under a peg is slightly more negative, but not statistically significant. A Wald test finds the interaction terms involving $F C D$ to be jointly significant, but not the terms with the double interaction $F C D * P E G$. With high foreign debt the response of output and investment is stronger, consistent with the interpretation that balance sheet effects become more important.
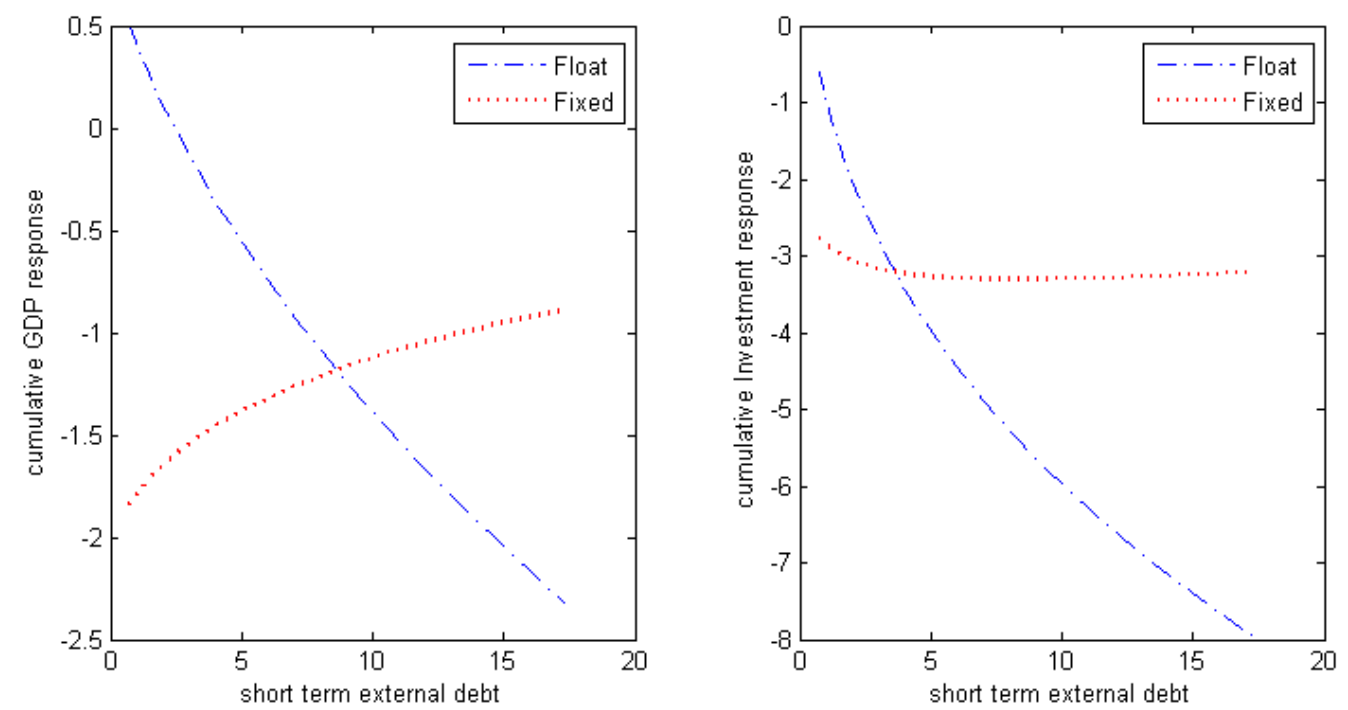

Figure 5. Cumulative Response of Output and Investment to a 10\% ToT Shock in the second year as a function of foreign currency debt 
Table 3. Output and Investment Response to External Shock, Conditional on Short Term External Debt and Exchange Rate Regime

\begin{tabular}{|c|c|c|c|c|c|c|c|}
\hline & & High FCD & & & Low FCD & & Diff High minus \\
\hline & PEG & FLOAT & Difference & PEG & FLOAT & Difference & Diff Low \\
\hline \multicolumn{8}{|c|}{$\begin{array}{l}10 \% \text { Tot Shock, LYS, short term external debt } \\
\text { output }\end{array}$} \\
\hline 1st year & -0.21 & $-0.37^{*}$ & 0.16 & $-0.67^{* * *}$ & -0.09 & $-0.59^{* *}$ & $0.74^{*}$ \\
\hline 2nd year & $-0.78^{* * *}$ & $-1.12^{* * *}$ & 0.34 & $-1.23^{* * *}$ & 0.14 & $-1.37^{* * *}$ & $1.71^{* *}$ \\
\hline $\begin{array}{l}\text { 5th year } \\
\text { investment }\end{array}$ & $-0.92^{* * *}$ & $-1.24^{* * *}$ & 0.32 & $-1.36^{* * *}$ & 0.08 & $-1.44^{* * *}$ & 1.76 \\
\hline 1st year & -0.81 & $-1.60^{*}$ & 0.79 & $-1.36^{*}$ & -0.75 & -0.61 & 1.39 \\
\hline 2nd year & $-2.80^{* * *}$ & $-4.52^{* * *}$ & 1.72 & $-1.67^{*}$ & -0.93 & -0.74 & 2.47 \\
\hline 5 th year & $-2.86^{* * *}$ & $-4.89^{* * *}$ & 2.03 & $-2.46^{*}$ & $-1.46^{*}$ & -1.00 & 3.03 \\
\hline Wald Test & 0.00 & 0.00 & 0.00 & & & & \\
\hline \multicolumn{8}{|c|}{$\begin{array}{l}10 \% \text { Tot Shock, IMF, short term external debt } \\
\text { output }\end{array}$} \\
\hline 1st year & -0.17 & $-0.23^{*}$ & 0.06 & $-0.31^{* *}$ & 0.09 & $-0.40^{* *}$ & $0.46^{*}$ \\
\hline 2nd year & $-0.62^{* * *}$ & $-0.64^{* * *}$ & 0.02 & $-0.72^{* * *}$ & 0.13 & $-0.85^{* * *}$ & $0.87^{*}$ \\
\hline $\begin{array}{l}\text { 5th year } \\
\text { investment }\end{array}$ & $-0.75^{* * *}$ & $-0.78^{* * *}$ & 0.03 & $-1.21^{* * *}$ & 0.16 & $-1.37^{* * *}$ & 1.39 \\
\hline 1st year & $-1.29^{* * *}$ & $-0.85^{*}$ & -0.44 & $-1.74^{* * *}$ & $1.10^{*}$ & $-2.84^{* * *}$ & $2.40^{* *}$ \\
\hline 2nd year & $-3.14^{* * *}$ & $-2.73^{* * *}$ & -0.41 & $-2.87^{* * *}$ & $2.22^{* *}$ & $-5.09^{* * *}$ & $4.68^{*}$ \\
\hline 5 th year & $-3.32^{* * *}$ & $-3.43^{* * *}$ & 0.11 & $-4.12^{* * *}$ & 1.36 & $-5.48^{* * *}$ & 5.59 \\
\hline Wald Test & 0.00 & 0.00 & 0.00 & & & & \\
\hline \multicolumn{8}{|c|}{$\begin{array}{l}\text { 10\% Tot Shock, LYS, external debt } \\
\text { output }\end{array}$} \\
\hline 1st year & -0.11 & -0.20 & 0.09 & $-0.56^{* * *}$ & -0.17 & $-0.39^{*}$ & $0.48^{*}$ \\
\hline 2nd year & $-0.72^{* * *}$ & $-0.52^{*}$ & -0.20 & $-1.16^{* * *}$ & -0.23 & $-0.93^{* *}$ & 0.72 \\
\hline $\begin{array}{l}\text { 5th year } \\
\text { investment }\end{array}$ & $-0.85^{* * *}$ & $-0.52^{*}$ & -0.33 & $-1.27^{* * *}$ & -0.35 & $-0.92^{*}$ & $0.59^{*}$ \\
\hline 1st year & -0.64 & $-1.34^{*}$ & 0.70 & $-1.69^{* *}$ & $-1.05^{*}$ & -0.64 & 1.34 \\
\hline 2nd year & $-2.35^{* * *}$ & $-3.40^{* * *}$ & 1.05 & $-2.93^{* * *}$ & -1.22 & -1.71 & 2.76 \\
\hline 5 th year & $-2.73^{* * *}$ & $-3.44^{* * *}$ & 0.72 & $-3.00^{* *}$ & $-2.11^{*}$ & -0.89 & 1.60 \\
\hline Wald Test & 0.00 & 0.00 & 0.05 & & & & \\
\hline \multicolumn{8}{|c|}{$\begin{array}{l}10 \% \text { Tot Shock, LYS, BIS } \\
\text { output }\end{array}$} \\
\hline 1st year & $0.31^{*}$ & $-0.39^{*}$ & $0.70^{* * *}$ & $-0.27^{*}$ & $-0.41^{* *}$ & 0.15 & $0.55^{*}$ \\
\hline 2nd year & $-0.62^{* * *}$ & $-1.12^{* * *}$ & 0.49 & $-0.61^{* *}$ & -0.30 & -0.31 & 0.80 \\
\hline $\begin{array}{l}\text { 5th year } \\
\text { investment }\end{array}$ & -0.31 & $-1.15^{* * *}$ & $0.85^{*}$ & $-0.67^{*}$ & -0.39 & -0.27 & 1.12 \\
\hline 1st year & 0.33 & -1.00 & $1.33^{*}$ & -0.47 & $-1.57^{*}$ & 1.11 & 0.23 \\
\hline 2nd year & $-1.55^{*}$ & $-3.71^{* * *}$ & 2.16 & -1.19 & $-2.39^{* *}$ & 1.20 & 0.96 \\
\hline 5 th year & -0.14 & $-3.42^{* *}$ & $3.29^{*}$ & -1.69 & $-2.20^{* *}$ & 0.51 & 2.77 \\
\hline Wald Test & 0.00 & 0.00 & 0.00 & & & & \\
\hline \multicolumn{8}{|c|}{$\begin{array}{l}\text { 100bps foreign interest rate shock, LYS, short term external debt } \\
\text { output }\end{array}$} \\
\hline 1st year & -0.06 & 0.12 & -0.18 & 0.13 & 0.14 & -0.01 & -0.17 \\
\hline 2nd year & $-0.26^{*}$ & -0.09 & -0.17 & -0.03 & 0.21 & -0.24 & 0.07 \\
\hline $\begin{array}{l}\text { 5th year } \\
\text { investment }\end{array}$ & $-0.45^{* *}$ & -0.27 & -0.19 & -0.15 & 0.10 & -0.25 & 0.07 \\
\hline 1st year & -0.52 & 0.70 & $-1.22^{*}$ & 0.54 & 0.28 & 0.27 & $-1.48^{*}$ \\
\hline 2nd year & -0.35 & -0.56 & 0.20 & -0.05 & -0.09 & 0.04 & $0.16^{*}$ \\
\hline 5 th year & $-2.13^{* * *}$ & $-1.58^{*}$ & -0.55 & -0.53 & -0.10 & -0.43 & -0.12 \\
\hline Wald Test & 0.00 & 0.00 & 0.20 & & & & \\
\hline
\end{tabular}



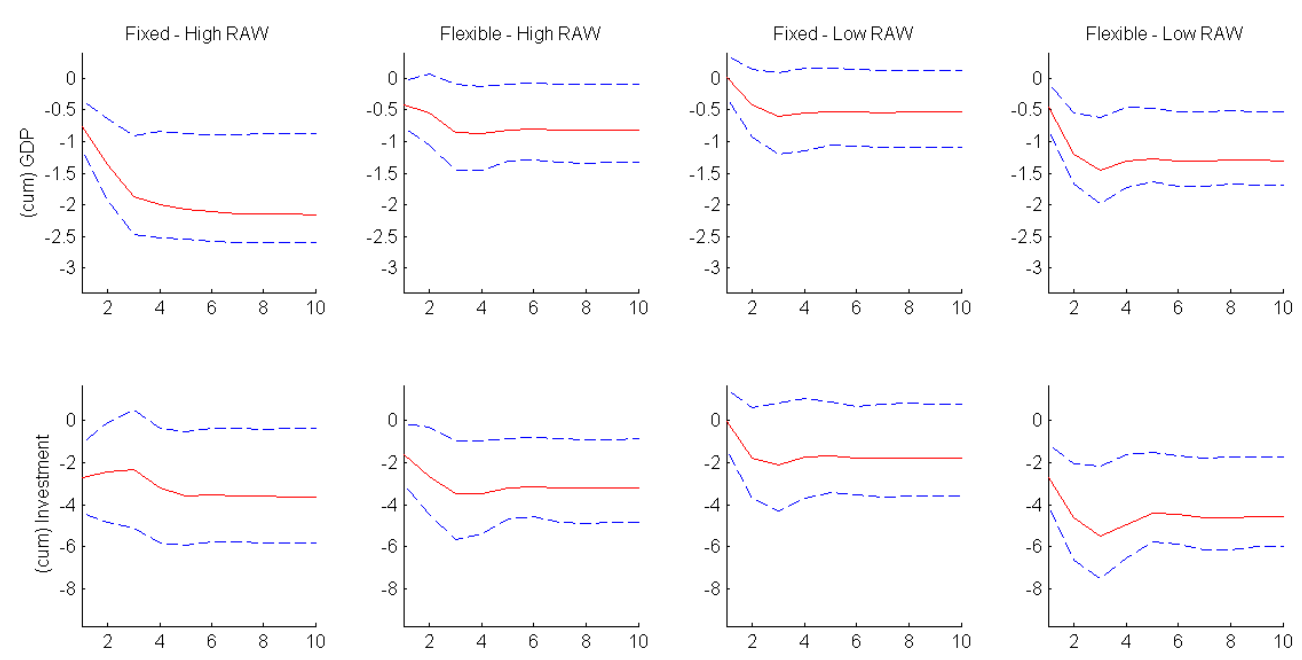

Figure 6. Impulse Responses for a Negative 10\% Terms of Trade Shock under LYS classification

\section{The Role of Import Structure}

In a next step we attempt to shed some light on the role of import structure in the transmission of shocks. Figure 6 shows the response of output and investment in countries with a high and a low share of raw materials in total imports. With a high share of raw materials and therefore high pass-through, flexible exchange rates shield output better from terms of trade shocks. In countries that have a high raw material share and maintain a peg output falls by about 1.5 percent in two years, while it falls only by a bit more than $0.5 \%$ under a float. For countries with low pass-through the picture is reversed. Under a peg output falls by $0.4 \%$ and under a float it falls by about $1.2 \%$. The differences are statistically significant in both cases. A potential explanation for the higher response under a float are balance sheet effects that can no longer by compensated with expenditure switching. The explanation is consistent with the response of investment. For observations with a low raw material share, investment falls by about $4.6 \%$ under a float and only by about $2.7 \%$ under a peg.

As with foreign currency we can investigate how the respective exchange rate regime performs by evaluating the cumulative output response at different levels of our import structure measure. Figure 7 shows the accumulated response of output in the second year for varying shares of raw materials on total imports. As expected we find that the insulation ability of the float increases with the raw material share, when expenditure switching dominates the balance sheet effect. For fixed regimes on the other hand, the response of output to terms of trade 
Figure 7. Cumulative Response of Output and Investment to a 10\% ToT Shock in the second year as a function of raw material share in total imports
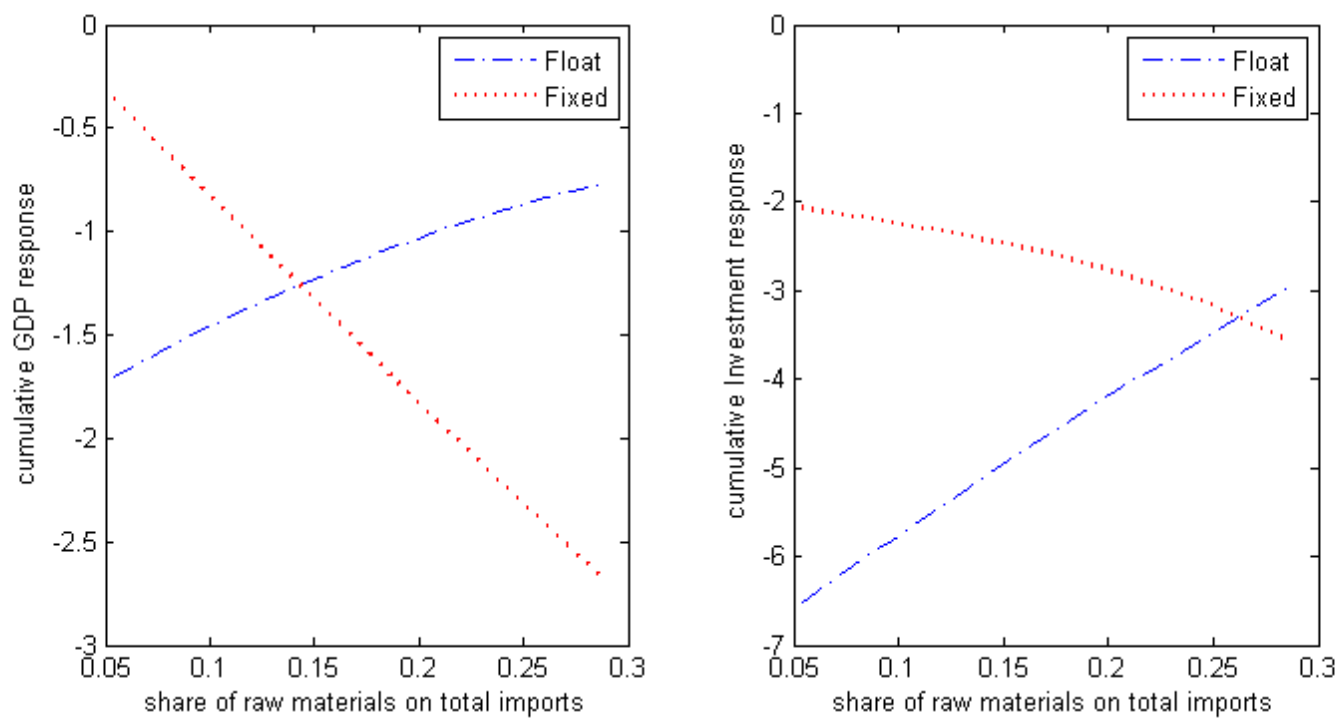

shocks increases with the pass-through. The response of pegs and floats intersect at a raw material share of $14 \%$. Roughly $55 \%$ of the observations lie below the threshold. ${ }^{24}$ If we use the de jure exchange rate classification a similar picture emerges, but the differences in pairwise comparison of impulse responses are smaller and not statistically significant (Table 4). The result is in line with our argument that actual exchange rate policy is more important than the declared, de jure policy. A Wald test finds joint significance of all interaction terms. If we analyze the response of output to a foreign interest rate shock, we again confirm the that flexible exchange rate insulates output only significantly better when raw material imports are relatively large.

\footnotetext{
${ }^{24}$ The discussed theory predicts that the response of output under a peg stays constant, whereas it actually falls in the data. As discussed above, a higher share of raw materials might also lead to other effects than higher exchange rate pass-trough, such as lower import substitutability. In that case a given terms of trade shock will have larger effects on output under both exchange rate regime, since the higher costs can be absorbed less easily. A negative correlation between exchange rate pass-trough and import substitutability would work against our finding that a higher raw material share improves the buffer properties of a floating exchange rate regime. The fact that we still find that output reacts less to the negative terms of trade shock therefore strengthens our case.
} 


\begin{tabular}{|c|c|c|c|c|c|c|c|}
\hline & PEG & $\begin{array}{l}\text { High RAW } \\
\text { FLOAT }\end{array}$ & Difference & PEG & $\begin{array}{l}\text { LOW RAW } \\
\text { FLOAT }\end{array}$ & Difference & $\begin{array}{l}\text { Diff High minus } \\
\text { Diff Low }\end{array}$ \\
\hline \multicolumn{8}{|c|}{$\begin{array}{l}10 \% \text { Tot Shock, LYS, Raw Material Import Share } \\
\text { output }\end{array}$} \\
\hline 1st year & $-0.75^{* * *}$ & $-0.41^{* *}$ & $-0.34^{*}$ & 0.03 & $-0.45^{* *}$ & $0.48^{* *}$ & $-0.82^{* *}$ \\
\hline 2nd year & $-1.36^{* * *}$ & $-0.56^{*}$ & $-0.80^{* *}$ & $-0.42^{*}$ & $-1.21^{* * *}$ & $0.79^{* *}$ & $-1.59^{* *}$ \\
\hline $\begin{array}{l}\text { 5th year } \\
\text { investment }\end{array}$ & $-2.07^{* * *}$ & $-0.82^{* *}$ & $-1.25^{* *}$ & $-0.52^{*}$ & $-1.28^{* * *}$ & $0.75^{*}$ & -2.00 \\
\hline 1st year & $-2.72^{* * *}$ & $-1.56^{* *}$ & -1.16 & 0.04 & $-2.66^{* * *}$ & $2.70^{* * *}$ & $-3.86^{* * *}$ \\
\hline 2nd year & $-2.44^{* *}$ & $-2.66^{* * *}$ & 0.22 & $-1.77^{*}$ & $-4.59^{* * *}$ & $2.82^{*}$ & -2.60 \\
\hline 5th year & $-3.55^{* * *}$ & $-3.20^{* * *}$ & -0.35 & -1.68 & $-4.40^{* * *}$ & $2.72^{*}$ & -3.07 \\
\hline Wald Test & 0.00 & 0.00 & 0.01 & & & & \\
\hline \multicolumn{8}{|c|}{$\begin{array}{l}10 \% \text { Tot Shock, IMF, Raw Material Import Share } \\
\text { output }\end{array}$} \\
\hline 1st year & $-0.29^{*}$ & $-0.33^{* * *}$ & 0.04 & -0.07 & $-0.20^{*}$ & 0.13 & -0.09 \\
\hline 2nd year & $-0.77^{* * *}$ & $-0.28^{*}$ & $-0.49^{*}$ & $-0.60^{* *}$ & $-0.76^{* * *}$ & 0.16 & $-0.65^{* *}$ \\
\hline $\begin{array}{l}\text { 5th year } \\
\text { investment }\end{array}$ & $-1.36^{* * *}$ & $-0.52^{*}$ & $-0.85^{*}$ & $-1.12^{* * *}$ & $-0.79^{* * *}$ & -0.34 & $-0.51^{* * *}$ \\
\hline 1st year & $-2.73^{* * *}$ & $-1.05^{* *}$ & $-1.68^{* *}$ & -0.49 & $-0.89^{*}$ & 0.40 & $-2.07^{* *}$ \\
\hline 2nd year & $-2.85^{* * *}$ & $-1.35^{*}$ & $-1.50^{*}$ & $-2.61^{* * *}$ & $-1.43^{*}$ & -1.18 & $-0.32^{*}$ \\
\hline 5 th year & $-4.00^{* * *}$ & $-2.03^{* * *}$ & $-1.97^{*}$ & $-3.82^{* * *}$ & $-2.19^{* *}$ & -1.62 & -0.35 \\
\hline Wald Test & 0.00 & 0.00 & 0.00 & & & & \\
\hline \multicolumn{8}{|c|}{$\begin{array}{l}\text { 100bps foreign interest rate shock, LYS, Raw Material Import Share } \\
\text { output }\end{array}$} \\
\hline 1st year & $-0.20^{*}$ & 0.12 & $-0.31^{*}$ & -0.02 & $0.23^{*}$ & $-0.25^{*}$ & -0.07 \\
\hline 2nd year & $-0.58^{* * *}$ & -0.01 & $-0.57^{*}$ & -0.15 & 0.03 & -0.17 & -0.39 \\
\hline $\begin{array}{l}\text { 5th year } \\
\text { investment }\end{array}$ & $-0.86^{* *}$ & -0.11 & $-0.75^{*}$ & -0.20 & -0.30 & 0.10 & -0.85 \\
\hline 1st year & -0.44 & 0.69 & $-1.12^{*}$ & 0.19 & $1.33^{* * *}$ & $-1.14^{*}$ & 0.02 \\
\hline 2nd year & $-1.31^{*}$ & -0.30 & -1.01 & -0.15 & 0.63 & -0.78 & -0.23 \\
\hline 5 th year & $-2.38^{* *}$ & -0.57 & -1.82 & -1.01 & -0.88 & -0.13 & -1.69 \\
\hline Wald Test & 0.00 & 0.00 & 0.10 & & & & \\
\hline
\end{tabular}

Table 4. Output and Investment Response to External Shock, Conditional on Import Structure and Exchange Rate Regime

\section{The Joint Role of Foreign Currency Debt and Import Structure}

Our results so far have shown that there is no empirical evidence that output responds generally less to a real shock under a float. Consistent with theoretical underpinnings we find that the insulation properties of floats vanish for import structures associated with low levels of pass-through and for high levels of foreign currency debt. We now turn to the complete specification and let the responses be a function of the exchange rate regime, foreign currency debt, and import structure. ${ }^{25}$ We take the value of the cumulated response of output within

\footnotetext{
${ }^{25}$ Results are in line with the former findings and confidence intervals remain reasonably tight. To save space results are not reported but available from the authors.
} 
two years as a benchmark and simulate this response along the grid of possible constellations of foreign currency debt and import structures for fixed regimes and flexible regimes. Then we subtract the corresponding value of the peg from the float. A value below zero implies the response of output under the float is stronger. The lower the value the stronger is the relative response under a float. Figure 8 confirm the previous findings and resembles the shape of Figure 1 from the theoretical model. The output response under a float is weaker if the raw material share is high and foreign debt is low. The picture weakens and finally reverses if either the raw material share is low or foreign debt is high.

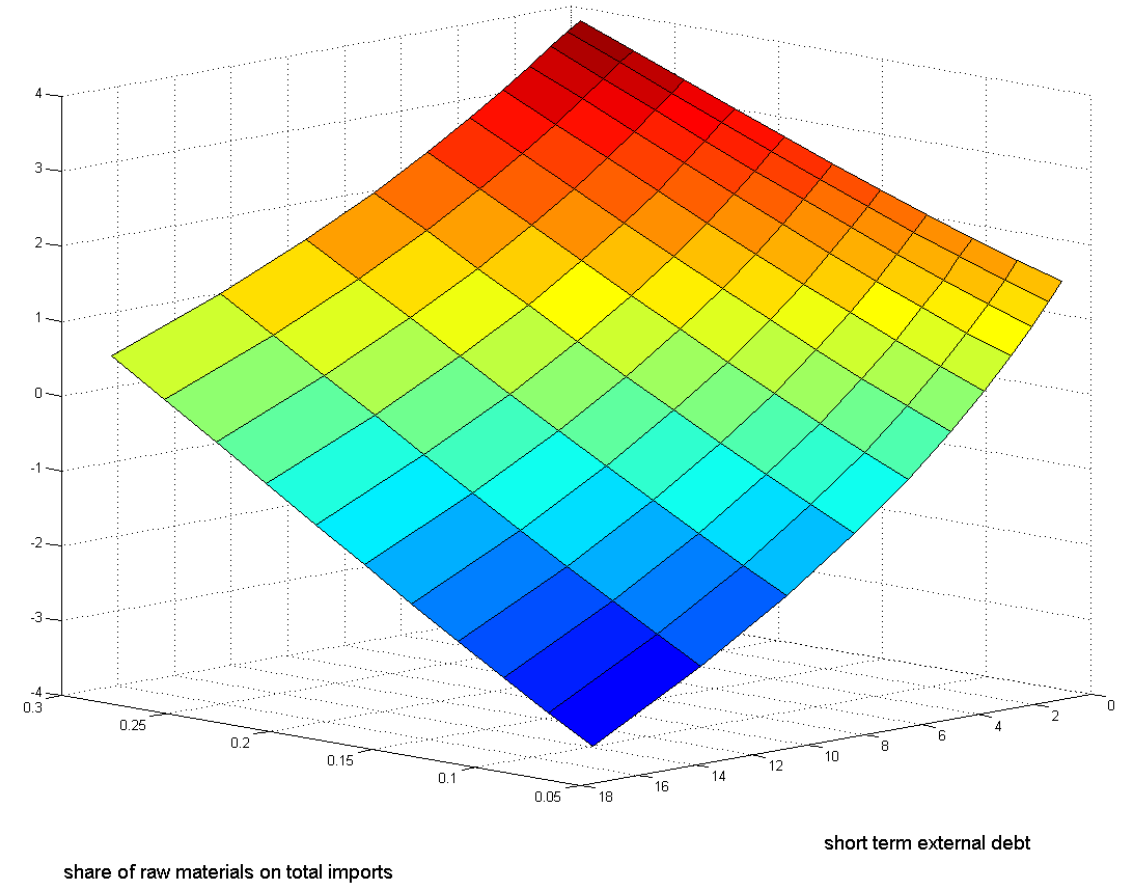

Figure 8. Output response to a negative $10 \%$ terms of trade shock in the second year: Difference between float and peg.

\section{Conclusion}

Various authors have pointed out the theoretical limitations of flexible exchange rate regimes in the presence of balance sheet effects and pricing to market. However, there is no agreement on whether these limitations can outweigh the stabilizing properties of flexible exchange rates. We provide empirical evidence that limited exchange rate pass-through can reduce the 
capacity of floating exchange rate regimes to buffer against external shocks and the presence of high foreign currency debt can even cause the flexible exchange rate regime to be more destabilizing than a peg. Previous studies on the role of exchange rate regimes have either not distinguished between the various shocks that hit the economy or not accounted for differences in the frictions or the economic structure that affect the response to shocks. Using an Interacted Panel VAR for a large sample of countries, we assess the role of foreign currency debt and limited pass-through, by allowing the response of output and investment to an external shock to vary with the exchange rate regime, the foreign currency debt and the import structure. We show that our findings are consistent with a stylized three equation IS-LM-BP model with foreign currency debt in the spirit of Céspedes, Chang, and Velasco (2003) which we extended to allow for limited pass-through. In this framework, a flexible exchange rate does not necessarily shield output better from real external shocks than pegs when foreign currency debt is high and pass-through low since contractionary balance sheet effects dominate the expansionary expenditure switching effects. While our results indicate that under a float output only tends to fall by less in response to an external shock if foreign debt is low and the import share of raw materials is high policy makers will also care about other aspects when choosing an exchange rate regime, such as its effects on inflation, trade volumes, long term growth or on the likelihood of financial crises. Our framework is silent on these dimensions, but our results suggest that ceteris paribus the case for a float weakens if a country has high foreign currency debt and imports mainly low pass-through goods due to the increased volatility. 


\section{REFERENCES}

Arteta, Carlos O., 2005, "Exchange Rate Regimes and Financial Dollarization: Does Flexibility Reduce Currency Mismatches in Bank Intermediation?" The B.E. Journal of Macroeconomics, Vol. 0, No. 1.

Baxter, Marianne, and Alan C. Stockman, 1989, "Business cycles and the exchange-rate regime : Some international evidence," Journal of Monetary Economics, Vol. 23, No. 3, pp. $377-400$.

Bebczuk, Ricardo N., Ugo Panizza, and Arturo Galindo, 2006, "An Evaluation of the Contractionary Devaluation Hypothesis," RES Working Papers 4486, Inter-American Development Bank, Research Department.

Bernanke, Ben, Mark Gertler, and Simon Gilchrist, 1998, "The Financial Accelerator in a Quantitative Business Cycle Framework," NBER Working Papers 6455, National Bureau of Economic Research, Inc.

Broda, Christian, 2004, "Terms of trade and exchange rate regimes in developing countries," Journal of International Economics, Vol. 63, No. 1, pp. 31-58.

Broda, Christian, and Cedric Tille, 2003, "Coping with terms-of-trade shocks in developing countries," Current Issues in Economics and Finance.

Campa, José Manuel, and Linda S. Goldberg, 2005, "Exchange Rate Pass-Through into Import Prices," The Review of Economics and Statistics, Vol. 87, No. 4, pp. 679-690.

Cavallo, Michele, Kate Kisselev, Fabrizio Perri, and Nouriel Roubini, 2005, "Exchange rate overshooting and the costs of floating," Working Paper Series 2005-07, Federal Reserve Bank of San Francisco.

Céspedes, Luis Felipe, Roberto Chang, and Andres Vélasco, 2004, "Balance Sheets and Exchange Rate Policy," American Economic Review, Vol. 94, No. 4, pp. 1183-1193.

Céspedes, Luis Felipe, Roberto Chang, and Andrés Velasco, 2003, "Must Original Sin Cause Macroeconomic Damnation?" Working Papers Central Bank of Chile 234, Central Bank of Chile.

Choi, Woon Gyu, and David Cook, 2004, "Liability dollarization and the bank balance sheet channel," Journal of International Economics, Vol. 64, No. 2, pp. 247-275.

Cook, David, 2004, "Monetary policy in emerging markets: Can liability dollarization explain contractionary devaluations?" Journal of Monetary Economics, Vol. 51, No. 6, pp. 11551181.

Devereux, Michael B., and Charles Engel, 2003, "Monetary Policy in the Open Economy Revisited: Price Setting and Exchange-Rate Flexibility," Review of Economic Studies, Vol. 70, No. 4, pp. 765-783. 
Devereux, Michael B., Philip R. Lane, and Juanyi Xu, 2006, "Exchange Rates and Monetary Policy in Emerging Market Economies," Economic Journal, Vol. 116, No. 511, pp. 478-506.

di Giovanni, Julian, and Jay C. Shambaugh, 2008, “The impact of foreign interest rates on the economy: The role of the exchange rate regime," Journal of International Economics, Vol. 74, No. 2, pp. 341-361.

Edwards, Sebastian, and Eduardo Levy Yeyati, 2005, "Flexible exchange rates as shock absorbers," European Economic Review, Vol. 49, No. 8, pp. 2079-2105.

Engel, Charles, 1993, "Real exchange rates and relative prices : An empirical investigation," Journal of Monetary Economics, Vol. 32, No. 1, pp. 35-50.

Fleming, John M., 1962, "Domestic Financial Policies under Fixed and under. Floating Exchange Rates," IMF StaffPapers 9, IMF StaffPapers.

Flood, Robert P., and Andrew K. Rose, 1995, "Fixing exchange rates A virtual quest for fundamentals," Journal of Monetary Economics, Vol. 36, No. 1, pp. 3-37.

Friedman, Milton, 1953, “The Case for Flexible Exchange Ratess,” Essays in Positive Economics.

Galindo, Arturo, Ugo Panizza, and Fabio Schiantarelli, 2003, "Debt composition and balance sheet effects of currency depreciation: a summary of the micro evidence," Emerging Markets Review, Vol. 4, No. 4, pp. 330-339.

Gertler, Mark, Simon Gilchrist, and Fabio M. Natalucci, 2007, "External Constraints on Monetary Policy and the Financial Accelerator," Journal of Money, Credit and Banking, Vol. 39, No. 2-3, pp. 295-330.

Ghosh, A.R., A.M. Gulde, and H.C. Wolf, 2002, Exchange Rate Regimes: Choices and Consequences (MIT Press).

Ghosh, Atish R., Anne-Marie Gulde, Jonathan D. Ostry, and Holger C. Wolf, 1997, "Does the Nominal Exchange Rate Regime Matter?" NBER Working Papers 5874, National Bureau of Economic Research, Inc.

Hausmann, Ricardo, Ugo Panizza, and Ernesto Stein, 2001, "Why do countries float the way they float?” Journal of Development Economics, Vol. 66, No. 2, pp. 387-414.

Hoffmann, Mathias, 2007, "Fixed versus Flexible Exchange Rates: Evidence from Developing Countries," Economica, Vol. 74, No. 295, pp. 425-449.

Kehoe, Timothy J., and Kim J. Ruhl, 2008, "Are Shocks to the Terms of Trade Shocks to Productivity?" Review of Economic Dynamics, Vol. 11, No. 4, pp. 804-819.

Kohlscheen, Emanuel, 2010, "Emerging floaters: Pass-throughs and (some) new commodity currencies," Journal of International Money and Finance, Vol. 29, No. 8, pp. 1580 - 1595. 
Krugman, Paul, 1986, "Pricing to Market when the Exchange Rate Changes," NBER Working Papers 1926, National Bureau of Economic Research, Inc.

Lane, Philip R., and Jay C. Shambaugh, 2010, "Financial Exchange Rates and International Currency Exposures," American Economic Review, Vol. 100, No. 1, pp. 518-40.

Levy-Yeyati, Eduardo, and Federico Sturzenegger, 2005, "Classifying exchange rate regimes: Deeds vs. words," European Economic Review, Vol. 49, No. 6, pp. 1603-1635.

Loayza, Norman, and Claudio E. Raddatz, 2007, “The Structural Determinants of External Vulnerability," The World Bank Economic Review, Vol. 21, No. 3, pp. 359-387.

Mendoza, Enrique G, 1995, "The Terms of Trade, the Real Exchange Rate, and Economic Fluctuations," International Economic Review, Vol. 36, No. 1, pp. 101-37.

Miniane, Jacques, and John H. Rogers, 2007, "Capital Controls and the International Transmission of U.S. Money Shocks," Journal of Money, Credit and Banking, Vol. 39, No. 5, pp. 1003-1035.

Mundell, Robert A., 1961, “A Theory of Optimum Currency Areas,” American Economic Review, , No. 51, pp. 657-665.

Mussa, Michael, 1986, "Nominal exchange rate regimes and the behavior of real exchange rates: Evidence and implications," Carnegie-Rochester Conference Series on Public Policy, Vol. 25, No. 1, pp. 117-214.

Pesaran, M. Hashem, and Ron Smith, 1995, "Estimating long-run relationships from dynamic heterogeneous panels," Journal of Econometrics, Vol. 68, No. 1, pp. 79-113.

Raddatz, Claudio, 2007, "Are external shocks responsible for the instability of output in lowincome countries?” Journal of Development Economics, Vol. 84, No. 1, pp. 155-187.

Ramcharan, Rodney, 2007, "Does the exchange rate regime matter for real shocks? Evidence from windstorms and earthquakes," Journal of International Economics, Vol. 73, No. 1, pp. $31-47$.

Rebucci, Alessandro, 2003, "On the Heterogeneity Bias of Pooled Estimators in Stationary VAR Specifications,” IMF Working Papers 03/73, International Monetary Fund.

Reinhart, Carmen M., and Kenneth S. Rogoff, 2004, “The Modern History of Exchange Rate Arrangements: A Reinterpretation," The Quarterly Journal of Economics, Vol. 119, No. 1, pp. $1-48$.

Rogoff, Kenneth, Ashoka Mody, Nienke Oomes, Robin Brooks, and Aasim M. Husain, 2004, "Evolution and Performance of Exchange Rate Regimes," IMF Occasional Papers 229, International Monetary Fund.

Runkle, David E., 1987, “Vector autoregressions and reality," Staff Report 107, Federal Reserve Bank of Minneapolis. 
Schneider, Martin, and Aaron Tornell, 2004, "Balance Sheet Effects, Bailout Guarantees and Financial Crises," Review of Economic Studies, Vol. 71, pp. 883-913.

Taylor, John B., 2000, "Low inflation, pass-through, and the pricing power of firms," European Economic Review, Vol. 44, No. 7, pp. 1389-1408.

Tsangarides, Charalambos G., 2010, "Crisis and Recovery: Role of the Exchange Rate Regime in Emerging Market Countries," IMF Working Papers 10/242, International Monetary Fund. 


\section{APPENDiX A. MODEL}

The model follows Céspedes, Chang, and Velasco (2003) microfounded IS-LM-BP model with sticky prices, wages, and a financial accelerator mechanism as in Bernanke, Gertler, and Gilchrist (1998) and extends it by investigating the consequences of limited exchange rate pass-through. Furthermore, to have a meaningful expenditure switching effect, we abandon the assumption of a unit elasticity of substitution between domestic and foreign goods. The model consists of a small open economy with two periods, 1 and 2. There are two types of agents: workers and entrepreneurs. We analyze the consequences of an adverse external demand shock in the initial period under different exchange regimes. In the second period no further shocks occur.

\section{A.1. Workers}

A worker's utility depends on consumption $\left(C_{t}\right)$, labor $\left(L_{t}\right)$ and real money holdings $\left(M_{t} / Q_{t}\right)$ in periods 1 and 2

$$
U=\sum_{t=1}^{2} \beta^{t}\left[\log C_{t}-\frac{\sigma-1}{\sigma} \frac{1}{v} L_{t}^{v}+\log \left(\frac{M_{t}}{Q_{t}}\right)\right] .
$$

Workers choose consumption and money holdings. They supply labor in a monopolistically competitive market. They set their wage one period in advance and then supply the amount of labor demanded by firms at the wage set. Log utility in consumption implies that expected labor supply will always be one $E_{t-1} L_{t}=1$. Consumption is an aggregate over domestic $\left(C_{H, t}\right)$ and foreign goods $\left(C_{F, t}\right)$

$$
C_{t}=v\left[\gamma C_{H, t}^{1-\phi}+(1-\gamma) C_{F, t}^{1-\phi}\right]^{\frac{1}{1-\phi}}
$$

where $\phi$ is the elasticity of substitution, $\gamma$ is a preference parameter related to the expenditure share of domestic goods and $v=\gamma^{-\gamma}(1-\gamma)^{-(1-\gamma)}$ is a constant. Foreign goods are a Cobb-Douglas composite of homogeneous goods $\left(C_{F, t}^{H O M}\right)$ with expenditure share $\omega$ and differentiated products $\left(C_{F, t}^{H E T}\right)$ with share $1-\omega .^{26}$

$$
C_{F, t}=\left(C_{F, t}^{H O M}\right)^{\omega}\left(C_{F, t}^{H E T}\right)^{1-\omega}
$$

\footnotetext{
${ }^{26}$ Both $C_{H, t}=\left[\int_{0}^{1} C_{H, j t}^{\frac{\theta-1}{\theta}} d j\right]^{\frac{\theta}{\theta-1}}$ and $C_{F, t}^{H E T}=\left[\int_{0}^{1}\left(C_{F, j t}^{H E T}\right)^{\frac{\theta-1}{\theta}} d j\right]^{\frac{\theta}{\theta-1}}$ are CES aggregates over varieties with elasticity of substitution $\theta$.
} 
The only asset workers can hold is money and the worker's budget constraint is

$$
Q_{t} C_{t}=W_{t} L_{t}+M_{t-1}-M_{t}+T_{t}
$$

Seignorage is rebated via lump sum transfers $T_{t}$ such that workers spend all income on consumption in equilibrium. The expenditure minimizing price index of the consumption bundle is

$$
Q_{t}=\left[\gamma P_{H, t}^{1-\phi}+(1-\gamma)\left\{\left(P_{F, t}^{H O M}\right)^{\omega}\left(P_{F t}^{H E T}\right)^{1-\omega}\right\}^{1-\phi}\right]^{\frac{1}{1-\phi}}
$$

where $P_{H, t}$ and $P_{F, t}^{H E T}$ are the expenditure minimizing price indices for home and foreign differentiated goods.

\section{A.2. Production and Price Setting}

Domestic varieties are produced by a continuum of firms $j$ with production function

$$
Y_{j t}=A K_{j t}^{\alpha} L_{j t}^{1-\alpha}
$$

where $K_{j t}$ is the firms's capital and composite labor is

$$
L_{j t}=\left[\int_{0}^{1} L_{i j t}^{\frac{\sigma-1}{\sigma}} d i\right]^{\frac{\sigma}{\sigma-1}}
$$

Firm $j$ maximizes profits $\Pi_{j t}=P_{j t} Y_{j t}-\int_{0}^{1} W_{i t} L_{i j t} d i-R_{t} K_{j t}$ and sets prices in advance. Profit maximization implies a constant markup over expected marginal costs $M C_{H, t}$.

$$
P_{H, t}=\frac{\theta}{\theta-1} E_{t-1} M C_{H, t}
$$

The market for foreign homogeneous goods is perfectly competitive. We normalize the foreign currency price of foreign homogeneous goods to one. The price in domestic currency is therefore the nominal exchange rate

$$
P_{F, t}^{H O M}=S_{t}
$$


Foreign firms producing differentiated goods set their price in domestic currency one period in advance at a mark-up over their expected marginal costs resulting in the price index ${ }^{27}$

$$
P_{F, t}^{H E T}=\frac{\theta}{\theta-1} E_{t-1} S_{t} M C_{F, t} .
$$

If a shock occurs, the exchange rate reacts, but because differentiated goods are priced in domestic currency, exchange rate pass-through to import prices will be limited.

\section{A.3. Entrepreneurs}

Entrepreneurs own domestic firms and provide capital. They start with a given amount of capital $K_{1}$ and a given external debt. The external debt can be denominated in foreign currency $\left(D_{1}^{*}\right)$ or domestic currency $\left(D_{1}\right)$. The investment good has the same composition as the consumption bundle and firms buy it at price $Q_{1}$. Capital depreciates completely after one period, so that investment is the capital stock in the next period. In the first period entrepreneurs buy capital. In the second period they use their profits to buy foreign goods. Entrepreneurs finance investment through their net worth and external debt.

$$
P_{1} N_{1}+S_{1} D_{2}^{*}+D_{2}=Q_{1} I_{1}
$$

Entrepreneur's net worth is the return on capital plus profits minus debt repayment

$$
P_{1} N_{1}=R_{1} K_{1}+\Pi_{1}-S_{1} D_{1}^{*}-D_{1}=P_{1} Y_{1}-W_{1} L_{1}-S_{1} D_{1}^{*}-D_{1}
$$

Because of capital market imperfections entrepreneurs pay a premium $\left(\eta_{1}\right)$ that increases with the ratio of investment over net worth. $\mu$ is a measure for the strength of imperfections. ${ }^{28}$

$$
1+\eta_{1}=\left(\frac{Q_{1} I_{1}}{P_{1} N_{1}}\right)^{\mu}
$$

Assuming entrepreneurs to be risk neutral, no arbitrage implies that the expected yield on capital equals the cost of foreign borrowing

$$
\frac{R_{2}}{Q_{1}}=(1+\rho)\left(1+\eta_{1}\right) \frac{S_{2}}{S_{1}}
$$

\footnotetext{
${ }^{27}$ For simplicity we assume that their marginal costs in foreign currency $M C_{t}^{F}$ are constant at $\frac{\theta-1}{\theta}$, which implies that, if no shocks occur, all foreign goods will be supplied at the same price $S_{t}$.

${ }^{28}$ Céspedes, Chang, and Vélasco (2004) provide a microfounded motivation for $\mu$.
} 
where $\rho$ is the foreign interest rate.

\section{A.4. Monetary Policy}

We consider two alternative monetary policies: an exchange rate peg, and a floating exchange rate. Small letters denote log deviations from the no shock equilibrium. Under a peg the exchange rate is constant

$$
s_{t}=0 .
$$

Under the float, the monetary authority keeps the money supply constant in the period where the shock occurs and lets the exchange rate adjust endogenously. Over the long term the authority cares about price stability and adjusts the money supply such that the price level in the second period stays constant.

$$
m_{1}=0, p_{2}=0 \text {. }
$$

We will show that this policy has a reduced form representation, which can be described by a rule under which the monetary authority lets it the exchange rate depreciate when an adverse shock occurs, given by:

$$
s_{t}=-\kappa y_{t}
$$

\section{A.5. Market Clearing}

In the initial period the demand for domestic goods comes from domestic consumption, domestic investment, and exports. Foreigners demand an exogenous amount of domestic goods denoted in foreign currency $X$.

$$
Y_{1}=\gamma\left(\frac{P_{1}}{Q_{1}}\right)^{-\theta}\left(I_{1}+C_{1}\right)+\frac{S_{1}}{P_{1}} X_{1}
$$

In the second period, there is no further investment and, given that entrepreneurs consume only imports, the market clearing condition is 


$$
Y_{2}=\gamma\left(\frac{P_{2}}{Q_{2}}\right)^{-\theta} C_{2}+\frac{S_{2}}{P_{2}} X_{2}
$$

\section{APPENDix B. DERIVATION OF THE IS-LM-BP EQUATIONS}

The steps follow closely Céspedes, Chang, and Velasco (2003) and are therefore brief.

\section{B.1. IS Curve}

Using the pricing rule and the fact that workers consume all income, the log linear version of the market clearing condition in period 2 (12) is

$$
y_{2}=\varkappa\left[(\phi-1)\left(q_{2}-p_{2}\right)+y_{2}\right]+(1-\varkappa)\left(s_{2}-p_{2}\right)
$$

where $\varkappa=\gamma(1-\alpha)\left(1-\theta^{-1}\right)\left(\frac{\bar{P}_{2}}{\bar{Q}_{2}}\right)^{1-\phi}$.

The $\log$ linearized version of the price index in period 2 is

$$
q_{2}=\left(1-\gamma_{2}^{\prime}\right) s_{2}+\gamma_{2}^{\prime} p_{2}
$$

where $\gamma_{2}^{\prime}=1-(1-\gamma)\left(\frac{\bar{S}_{2}}{\bar{Q}_{2}}\right)^{(1-\phi)} \cdot{ }^{29}$ Using equations (13) and (14) gives output as a function of the real exchange rate

$$
y_{2}=\Xi\left(s_{2}-p_{2}\right),
$$

where $\Xi=\left[1+(\phi-1)\left(1-\gamma_{2}^{\prime}\right) \varkappa /(1-\varkappa)\right] \geq 1$.

Using (15) in the log linear version of (7) the consumption level in period 2 is given by

$$
c_{2}=y_{2}-\left(q_{2}-p_{2}\right)
$$

\footnotetext{
${ }^{29}$ The share of differentiated goods plays no role, because no shocks occur in the second period and foreign producers of differentiated goods take shocks in the initial period into account.
} 
Since no shock occurs in the second period $l=0$, output deviations in the second period are driven by investment.

$$
y_{2}=\alpha i_{1}
$$

The linearized version of the market clearing condition in the first period (11) is

$$
\begin{aligned}
& \tau y_{1}+(1-\tau)\left[c_{1}+\phi q_{1}\right]=\lambda\left[i_{1}+\phi q_{1}\right]+(1-\lambda)\left(s_{1}+x_{1}\right) \\
& \text { where } \tau=\frac{1}{1-\gamma\left(\frac{\bar{P}_{1}}{\bar{Q}_{1}}\right)^{-\phi}(1-\alpha)\left(1-\theta^{-1}\right)}>1 \text { and } \lambda=\frac{\gamma\left(\frac{\bar{P}_{1}}{\bar{Q}_{1}}\right)^{-\phi} \bar{I}_{1}}{\gamma\left(\frac{\bar{P}}{\bar{Q}}\right)^{-\phi} \bar{I}_{1}+\frac{\bar{S}_{1}}{\bar{P}_{1}} \bar{X}_{1}}<1 .
\end{aligned}
$$

Since capital is predetermined and wages are preset we have from the workers budget constraint (7).

$$
q_{1}+c_{1}=\frac{y_{1}}{1-\alpha}
$$

The price index in period 1 is

$$
q_{1}=\left(1-\gamma_{1}^{\prime}\right) \omega s_{1}
$$

where $\gamma_{1}^{\prime}=1-(1-\gamma)\left(\frac{\bar{S}_{1}}{\bar{Q}_{1}}\right)^{(1-\phi)}$. Combining (18), (19) and (20) gives the IS curve

$$
A y_{1}=\lambda i_{1}+(1-\lambda) x_{1}+[(1-\lambda)+\lambda \omega g(\phi)] s_{1}
$$

where $A$ is given by $\left(\frac{1-\tau \alpha}{1-\alpha}\right) . \tau>1$ is the ratio of output to output net of consumption and $\alpha$ is the capital share in production and $g(\phi)=\left(1-\gamma_{1}^{\prime}\right)[\phi+(\phi-1)(\tau-1) / \lambda]$.

\section{B.2. LM: Money Demand}

From the consumer maximization problem we have that the log linear version of money demand in period one and two is respectively

$$
\begin{aligned}
\zeta\left(m_{1}-q_{1}\right)+(1-\zeta)\left(c_{2}+q_{2}-q_{1}\right) & =c_{1} \\
\zeta\left(m_{2}-q_{2}\right) & =c_{2}
\end{aligned}
$$


where $\zeta=1-\beta \bar{Q}_{1} \bar{C}_{1} / \bar{Q}_{2} \bar{C}_{2}$, which is assumed to be positive. Combining the above equation with (16), (17), (19), and (20) gives

$$
m_{1}=\frac{1}{\zeta} \frac{y_{1}}{1-\alpha}-\frac{(1-\zeta)}{\zeta} \alpha i_{1}-\frac{(1-\zeta)}{\zeta} p_{2}
$$

The LM schedule which describes the demand for money $\left(m_{1}\right)$ under the float is thus given by: $:^{30}$

$$
m_{1}=B y_{1}-C i_{1}
$$

where $B=\frac{1}{\zeta(1-\alpha)}$ and $C=\frac{(1-\zeta) \alpha}{\zeta}$ are positive constants. Money demand increases with output and decreases with investment, since for a given output more investment means less consumption, which depresses money demand. Under the peg the money supply adjusts.

\section{B.3. BP: Entrepreneurs}

The return on investment must satisfy the arbitrage condition with foreign returns adjusted by a risk premium

$$
r_{2}-q_{1}-p_{2}=\rho+\eta_{1}+\left(s_{2}-p_{2}\right)-s_{1}
$$

The marginal product of capital is given by $r_{2}-p_{2}=-i_{1}(1-\alpha)$. Using this result, (20) and (15) gives:

$$
i_{1} \Phi^{-1}=-\left(\rho+\eta_{1}\right)+[1-(1-\gamma) \omega] s_{1}
$$

where $\Phi=\frac{\Xi}{\Xi(1-\alpha)+\alpha} \geq 1$.

The log linear version of the risk premium is

$$
\eta_{1}=\mu\left[q_{1}+i_{1}-n_{1}\right]
$$

The log linear version of net worth equation

$$
n_{1}=(1+\psi) \delta_{y} y_{1}-\psi \xi s_{1}
$$

where $\delta_{y}=\theta^{-1}\left[1-(1-\alpha)\left(1-\theta^{-1}\right)\right]^{-1}$ and $\psi=\left(S_{1} D_{1}^{*}+D_{1}\right) / P_{1} N_{1}$ is the debt to net worth ratio.

\footnotetext{
${ }^{30}$ The LM curve is independent of the exchange rate due to the log in real money holdings. Allowing a more general framework does not affect the results.
} 
Using (28) in (27) gives:

$$
\eta=\mu\left\{i-(1+\psi) \delta_{y} y+[(1-\gamma) \omega+\psi \xi] s\right\}
$$

which can be used in (26) to derive the BP schedule: ${ }^{31}$

$$
\Gamma i_{1}=-\rho+\mu(1+\psi) \delta_{y} y_{1}-\mu[(1-\gamma) \omega+\psi \xi] s_{1}+[1-(1-\gamma) \omega] s_{1}
$$

Note also that there is a direct link between $\psi$ and the share of debt to GDP. To see this note that

$$
\begin{aligned}
\frac{\bar{P}_{1} \bar{N}_{1}}{\bar{P}_{1} \bar{Y}_{1}}= & \frac{\bar{R}_{1} \bar{K}_{1}+\bar{\Pi}_{1}}{\bar{P}_{1} \bar{Y}_{1}}-\frac{\bar{S}_{1} \bar{D}_{1}^{*}}{\bar{P}_{1} \bar{Y}_{1}}-\frac{\bar{D}_{1}}{\bar{P}_{1} \bar{Y}_{1}} \\
& =\frac{\bar{P}_{1} \bar{Y}_{1}-\bar{W}_{1} \bar{L}_{1}}{\bar{P}_{1} \bar{Y}_{1}}-\frac{\bar{S}_{1} \bar{D}_{1}^{*}}{\bar{P}_{1} \bar{Y}_{1}}-\frac{\bar{D}_{1}}{\bar{P}_{1} \bar{Y}_{1}}
\end{aligned}
$$

Using the standard pricing rule $\frac{\bar{W}_{1} \bar{L}}{\bar{P}_{1} \bar{Y}_{1}}=(1-\alpha) \frac{\theta-1}{\theta}$ this implies

$$
\frac{\bar{P}_{1} \bar{N}_{1}}{\bar{P}_{1} \bar{Y}_{1}}=1-(1-\alpha)\left(1-\theta^{-1}\right)-\frac{\bar{S}_{1} \bar{D}_{1}^{*}+\bar{D}_{1}}{\bar{P}_{1} \bar{Y}_{1}}
$$

Varying the share of foreign currency debt to GDP ratio $\left(\bar{S}_{1} \bar{D}_{1}^{*} / \bar{P}_{1} \bar{Y}_{1}\right)$ gives the implied $\left(\bar{P}_{1} \bar{N}_{1} / \bar{P}_{1} \bar{Y}_{1}\right)$ ratio (for a given level of domestic debt $\bar{D}_{1} / \bar{P}_{1} \bar{Y}_{1}$ ), which in turn allows to determine the total debt to net worth ratio $\psi=\left(S_{1} D_{1}^{*}+D_{1}\right) / P_{1} N_{1}$ and the implied foreign currency share in total debt ratio $\xi=\bar{S}_{1} \bar{D}_{1}^{*} /\left(\bar{S}_{1} \bar{D}_{1}^{*}+\bar{D}_{1}\right)$. Consider the standard parametrization $\theta=11$ and $\alpha=1 / 3$ then we have for a domestic debt to GDP ratio of $12 \%$ and a foreign debt to GDP ratio of $24 \%$ that $\bar{P}_{1} \bar{N}_{1} / \bar{P}_{1} \bar{Y}_{1}=0.04$ and $\psi=9$ and $\xi=2 / 3$.

\section{APpendix C. Solving the System}

In the following we use equations (1), (2) and (24) and combine them with the monetary policy to determine the respective implied response of output and investment to an external demand shock.

\footnotetext{
${ }^{31}$ Where $\Gamma=\left(\Phi^{-1}+\mu\right)$,
} 


\section{C.1. The Peg}

Under a peg monetary policy is given by $s=0$. This simplifies the system which determines output and investment to the following two equations:

$$
\begin{gathered}
A y=\lambda i+(1-\lambda) x \\
\Gamma i=-\rho+\mu(1+\psi) \delta_{y} y
\end{gathered}
$$

The impact of a terms of trade shock on output and investment is determined by solving the system and taking a derivate with respect to the external demand shock which yields the following two equations:

$$
\begin{gathered}
\left.\frac{\partial y}{\partial x}\right|^{P E G}=\frac{(1-\lambda) \Gamma}{A \Gamma-\lambda \mu(1+\psi) \delta_{y}} \\
\left.\frac{\partial i}{\partial x}\right|^{P E G}=\left.\frac{\partial y}{\partial x}\right|^{P E G} \frac{\mu(1+\psi) \delta_{y}}{\Gamma}=\frac{(1-\lambda) \mu(1+\psi) \delta_{y}}{A \Gamma-\lambda \mu(1+\psi) \delta_{y}}
\end{gathered}
$$

It is evident that the response of output and investment to an external demand shock is independent of the import share of differentiated goods $(\omega)$ and the level of foreign currency debt ( $\xi$ ) (Result 1). The strength of the response increases with leverage $\psi$, as it amplifies the balance sheet effect related to a fall in output. The investment response is a multiple of the the output response as illustrated in (32) and increases with leverage and the level of financial imperfection (Results 2). With no imperfection $\mu=0$ investment does not respond, since financing costs do not move. ${ }^{32}$

\footnotetext{
${ }^{32}$ With no capital market imperfections $(\mu=0)$ the solution simplifies to $\frac{\partial y}{\partial x}=(1-\lambda)(1-\tau \alpha) /(1-\alpha)$. Since investment is independent of output, the reaction of output remains only a function of the importance of the external demand in total output.
} 


\section{C.2. The Float}

We combine the IS and BP equation (1), (2) with the rule under the float (4). We can split the effect of the external shock on output under the float $\left(\left.\frac{\partial y}{\partial x}\right|^{F L}\right)$ in six separate components:

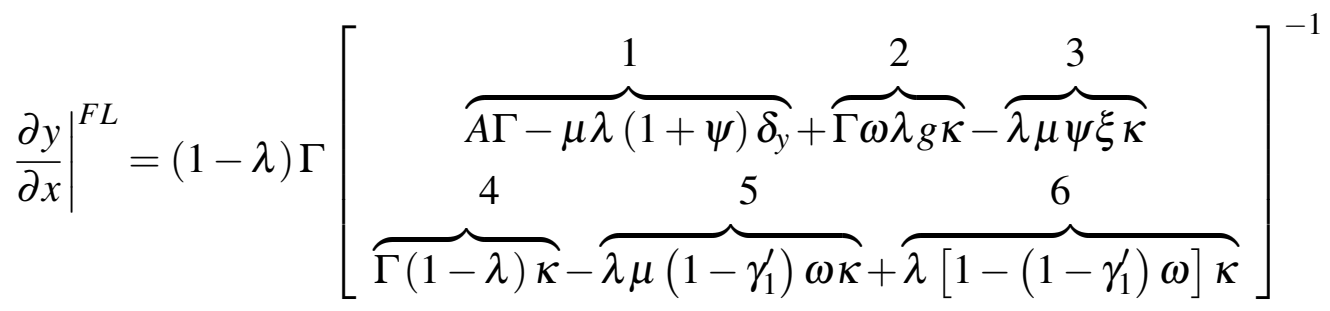

The first effect is identical to the peg. The other terms are a function of the exchange rate sensitivity parameter $\kappa .{ }^{33}$ Accordingly, $\kappa=0$ replicates the peg. The second and fourth terms stand for two channels that make depreciations expansionary. The second term reflects the expenditure switching effect: high pass-through (high $\omega$ ) and high substitution elasticity (high $g$ ) dampen the effects of an external demand shock. The fourth term reflects the export value effect which is increasing in the export share $(1-\lambda)$. The third and fifth terms stem from financial imperfections and can make depreciations contractionary because they affect the ratio of investment over net worth. The third term is the balance sheet effect related to the share of foreign debt: the higher $\xi$ the more destabilizing is a countercyclical exchange rate policy. The fifth term reflects the investment cost effect on the risk premium. The last term is the real risk free rate effect. It follows that higher foreign currency debt and a lower share of homogeneous goods diminish the moderating effects of a float:

$$
\begin{gathered}
\frac{\partial\left(\frac{\partial y}{\partial x}\right)}{\partial \xi}=\left[\frac{\partial y}{\partial x}\right]^{-2} \frac{\lambda}{(1-\lambda)} \frac{\mu \kappa \psi}{\Gamma}>0, \\
\frac{\partial\left(\frac{\partial y}{\partial x}\right)}{\partial \omega}=\left[\frac{\partial y}{\partial x}\right]^{-2}\left[\left(1-\gamma_{1}^{\prime}\right) \frac{(1+\mu)}{\Gamma}-g\right] \frac{\lambda \kappa}{(1-\lambda)}<0 .
\end{gathered}
$$

The inequality in (34) follows immediately from all coefficients being positive. For (35) the sign of the derivative depends on the second term in brackets, which reflects the relative importance of the real risk free rate and investment cost effect as opposed to the expenditure switching effect. In section C. 4 we proof that for $\phi>1$ the second term is always negative.

\footnotetext{
${ }^{33}$ We assume $\kappa$ not too strong, such that $\partial y / \partial x>0$.
} 
Thus, the ability of a float to stabilize the economy diminishes with the share of imported differentiated goods and the level of foreign currency debt (Results 3 ). We can calculate the threshold for which such a policy becomes actually more destabilizing than a peg by setting the sum of all the terms that multiply $\kappa$ in (33) equal to zero.

$$
\xi_{0}=\frac{(1-\lambda) \Gamma+\lambda}{\lambda \mu \psi}+\frac{\Gamma \lambda g-\lambda(1+\mu)\left(1-\gamma_{1}^{\prime}\right)}{\lambda \mu \psi} \omega_{0}
$$

An economy reaches the threshold foreign currency debt share more quickly if exchange rate pass-through $\omega_{0}$ is low, such that the expenditure switching effects are small, and leverage and financial imperfections are strong (Result 4). Note that the threshold is independent of the strength of countercyclicality $\kappa$.

The response of investment under the float is

$$
\begin{aligned}
\left.\frac{\partial i}{\partial x}\right|^{F L} & =\left.\Gamma^{-1} \mu(1+\psi) \delta_{y} \frac{\partial y}{\partial x}\right|^{P E G}-\Gamma^{-1} \mu(1+\psi) \delta_{y}\left[\left.\frac{\partial y}{\partial x}\right|^{P E G}-\left.\frac{\partial y}{\partial x}\right|^{F L}\right] \\
& +\left.\left\{\mu\left[\left(1-\gamma_{1}^{\prime}\right) \omega+\psi \xi\right]-\left[1-\left(1-\gamma_{1}^{\prime}\right) \omega\right]\right\} \Gamma^{-1} \kappa \frac{\partial y}{\partial x}\right|^{F L}
\end{aligned}
$$

The first two terms capture the effect of a change in output on net worth and the external finance premium. The third term in brackets captures the additional effects that come from exchange rate changes, since $\frac{\partial s}{\partial x}=-\kappa \frac{\partial y}{\partial x}$. The first terms within the brackets stand for the effects of a depreciation on the risk premium, both via increasing the price of investment and by increasing the domestic currency value of foreign debt. The second part captures the effect on the domestic real risk free interest rate and is independent of the level of financial frictions. A higher share of foreign currency debt increases the response of investment (Result 5). The effect of the import structure is ambiguous, because limited pass-through moderates the effect on prices, but increases the effect on output. The derivative with respect to $\omega$ is

$$
\begin{aligned}
\left.\frac{\partial i}{\partial x \partial \omega}\right|^{F L} & =\left.\frac{\mu(1+\psi) \delta_{y}}{\left(\Phi^{-1}+\mu\right)} \frac{\partial y}{\partial x \partial \omega}\right|^{F L}+\left.\left[\frac{\mu\left[\left(1-\gamma^{\prime}\right) \omega+\psi \xi\right]}{\left(\Phi^{-1}+\mu\right)}-\frac{\left[1-\left(1-\gamma^{\prime}\right) \omega\right]}{\left(\Phi^{-1}+\mu\right)}\right] \kappa \frac{\partial y}{\partial x \partial \omega}\right|^{F L} \\
& +\left.\frac{\mu\left[\left(1-\gamma^{\prime}\right)\right]+\left(1-\gamma^{\prime}\right)}{\left(\Phi^{-1}+\mu\right)} \kappa \frac{\partial y}{\partial x}\right|^{F L}
\end{aligned}
$$

For $\mu>0$ the first term is unambiguously negative, the third term is unambiguously positive, and the sign of the second term is ambiguous, which makes the sign of the overall expression 
ambiguous (Result 6). With high leverage the effect on output $\left(\left.\frac{\partial y}{\partial x}\right|^{P E G}-\left.\frac{\partial y}{\partial x}\right|^{F L}\right)$ dominates.

\section{C.3. The Pure Float}

In the following we show how the float can be derived as a reduced form representation of a pure float. The latter is given by a rule that stabilizes the money supply in the short run and the price level in the medium run. Using the definition of the pure float (9) in the money market equilibrium (23) implies for the LM that

$$
i=\frac{1}{(1-\zeta)(1-\alpha) \alpha} y
$$

Using this result in the BP yields:

$$
s=-\kappa(\omega, \xi) y
$$

where $\kappa(\omega, \xi)=B\left[(1+\mu)\left(1-\gamma^{\prime}\right) \omega+\mu \psi \xi-1\right]^{-1}$ and $B=\left(\Phi^{-1}+\mu\right)[(1-\zeta)(1-\alpha) \alpha]^{-1}-$ $\mu(1+\psi) \delta_{y}$. The system is completed by the IS equation (1). Thus for an appropriately chosen $\kappa=\kappa(\xi, \omega)$ the float can replicate the pure float. The difference between the two is that $\kappa$ adjusts to the different parameter values. To reestablish the equilibrium in the money market, the pure float generates endogenously a higher depreciation, if pass-through is lower $\left(\frac{\partial \kappa}{\partial \omega}<0\right)$. This insulates output better, through stronger expenditure switching, if foreign debt is low. For the same reason, the pure float insulates output worse if foreign debt is high and the share of differentiated goods in total imports is high, since now the stronger depreciation amplifies the contractionary effects.

\section{C.4. Evaluating the response of $\partial^{2} y / \partial x \partial \omega$}

To proof that the derivative $\partial^{2} y / \partial x \partial \omega<0$ we proceed in two steps. First, we show that for $\mu=0$ we obtain a negative value for the derivative. Second, we show that the value is continuously decreasing in $\mu$. Thus, the derivative can only be positive if $\mu<0$ which is not in the possible set of values.

Consider the term in brackets in (35). Substituting out $g(\phi)=\left(1-\gamma_{1}^{\prime}\right)[\phi+(\phi-1)(\tau-1) / \lambda]$ we can write.

$$
\frac{(1+\mu)}{\left(\Phi^{-1}+\mu\right)}\left(1-\gamma_{1}^{\prime}\right)-g=\left(1-\gamma_{1}^{\prime}\right)\left\{\frac{(1+\mu)}{\left(\Phi^{-1}+\mu\right)}-[\phi+(\phi-1)(\tau-1) / \lambda]\right\},
$$


since $\left(1-\gamma_{1}^{\prime}\right)>0$, it is sufficient to determine the sign of the term in curly brackets.

Now consider $\mu=0$. Since $\Phi=\frac{\Xi}{\Xi(1-\alpha)+\alpha} \geqslant 1$, multiplying all terms with $\Phi^{-1}$ will not change the sign of term in curly brackets and we have:

$$
1-\alpha \frac{\left[\phi+(\phi-1) \frac{\tau-1}{\lambda}\right]}{\Xi}-(1-\alpha)\left[\phi+(\phi-1) \frac{\tau-1}{\lambda}\right] \leq 0
$$

The inequality follows form the fact that for $\phi=1$, we have $\Xi=1$ and thus the entire term is zero. For any value of $\phi>1$ the term is negative since $\frac{\left[\phi+(\phi-1) \frac{\tau-1}{\lambda}\right]}{\Xi}$ and $\left[\phi+(\phi-1) \frac{\tau-1}{\lambda}\right]$ are increasing in $\phi$. The last step is to show that (39) is decreasing in $\mu$. This is the case since $g$ and $\gamma_{1}^{\prime}$ are independent of $\mu$ and $\frac{\partial\left[(1+\mu) /\left(\Phi^{-1}+\mu\right)\right]}{\partial \mu}<0$ since $\Phi^{-1}<1$ for $\phi>1$.

\section{ApPendix D. Data Sources}

In the following we describe the indices and transformations which we applied to the data:

Exchange Rate Regimes: The de jure classification needed to be unified since it is based on the changing IMF Annual Report on Exchange Arrangements and Exchange Restrictions (AREAER). The classification went through four distinct phases of change. It is possible to group the countries consistently into 3 broad categories, floating, intermediate and fixed regimes. The original IMF classification is coded in four taxonomies: Taxonomy 1 from 1975 to 1976 includes: "Pegged to a single currency" (1), "Pegged to a composite (including the SDR)" (2), "Floating - adjusted according to a set of indicators" (3), "Floating - common margins" (4) and "Floating - independently" (5). Taxonomy 2 from 1977 to 1981 distinguishes: "Pegged to a single currency" (1), "Pegged to a composite (including the SDR)" (2), "Adjusted according to a set of indicators" (3), "Cooperative exchange arrangements" (4), "Other" (5). Taxonomy 3 ranges from 1982 to 1998 with: "Pegged to a single currency" (1), "Pegged to a composite (including the SDR)" (2), "Flexibility limited vis-à-vis a single currency" (3), "Flexibility limited visà-vis a cooperative arrangement" (4), "Adjusted according to a set of indicators" (5), "Other managed floating" (6) and "Independently floating" (7). Taxonomy 4 from 1998 to today: "Exchange arrangement with no separate legal tender" (1), "Currency board arrangement" (2), "Conventional pegged arrangement" (3), "Conventional peg to a basket" (3,5), "Pegged exchange rate within horizontal bands" (4), "Crawling peg" (5), "Crawling band" (5), "Managed floating (7) and "Independently floating" (8). The "harmonized" IMF de jure classification is then based on the following mapping: 


\begin{tabular}{l|r|r|r|r|}
\multirow{2}{*}{$\begin{array}{l}\text { New } \\
\text { Unified }\end{array}$} & \multicolumn{4}{|c|}{ Former Classifications } \\
\cline { 2 - 5 } & Tax 1 & Tax 2 & Tax 3 & \multicolumn{1}{c|}{ Tax 4 } \\
\hline \hline Peg & 1,2 & 1,2 & 1,2 & $1,2,3,3,5$ \\
Interm & 3,4 & $3,4,5^{*}$ & $3,4,5,6$ & $4,5,6,7$ \\
Float & 5 & $5^{*}$ & 7 & 8 \\
\hline \hline
\end{tabular}

Import Structure: The share of primary commodities in total imports is proxied by the sum of agricultural goods, fuels, ores and metals over total imports. We use the data on shares of imports according to various product groups as provided by the WDI. We rescale the shares in terms of total imports of goods and services rather than merchandise imports. Hence, the import structure measure is:

$$
\text { PASS }=\log \left(1+\frac{\sum \text { raw material imports }}{\text { total imports }} * 100\right)
$$

where we take the log to limit the role of outliers.

Terms of Trade: Despite the fact that the IFS, the WDI (net barter terms of trade) and UNCTAD provide terms of trade data, they are not covering the entire sample. To enlarge the sample we constructed a proxy based on current and constant values of export and import data. In particular we used exports and imports in constant US dollars and current US dollars to construct the TOT proxy

$$
T o T=\frac{\frac{\text { EXPORTScur }}{\text { EXPORTScon }}}{\text { IMPORTScur }}
$$

which we scale to the base year 2000 to make the measure comparable to the IFS data. ${ }^{34}$ Our final terms of trade measure uses this measure, if the other measures do not provide sufficiently large series. As a check we use consistently our ToT proxy for all countries.

The choice for the indicator employed follows the length of the available series using if possible IFS then UNCTAD and then the implied terms of trade from the WDI constant and current value of exports and imports. Whenever a country's terms of trade remains unchanged for three consecutive years or has breaks in the series an alternative classification is preferred. The respective countries in the sample and the term of trade measure used is given below:

\footnotetext{
${ }^{34}$ Other authors have used this approach before. See for instance Loayza and Raddatz (2007) or Kehoe and Ruhl (2008)
} 


\begin{tabular}{|c|c|c|}
\hline Albania & Ghana & Panama \\
\hline Algeria & Greece $^{1}$ & Papua New Guinea \\
\hline Argentina & Guatemala & Paraguay ${ }^{2}$ \\
\hline Australia $^{1}$ & Guinea $^{2}$ & Peru \\
\hline Austria & Honduras & Philippines \\
\hline Azerbaijan & Hong Kong, China $^{1}$ & Poland ${ }^{1}$ \\
\hline Bangladesh & Hungary & Portugal \\
\hline Belarus & India & Romania \\
\hline Belgium & Indonesia & Russian Federation \\
\hline Benin & Iran, Islamic Rep. & Saudi Arabia ${ }^{2}$ \\
\hline Bolivia & Ireland $^{1}$ & Senegal \\
\hline Botswana & Israel $^{1}$ & Singapore ${ }^{1}$ \\
\hline Brazil & Jordan $^{1}$ & Slovak Republic \\
\hline Bulgaria & Kazakhstan & Slovenia \\
\hline Burkina Faso & Kenya & South Africa \\
\hline Cambodia & Korea, Rep. & Spain \\
\hline Cameroon & Kuwait & Sri Lanka ${ }^{1}$ \\
\hline Chad & Kyrgyz Republic & Sweden $^{1}$ \\
\hline Chile & Latvia & Switzerland \\
\hline China & Lebanon & Syrian Arab Republic \\
\hline Colombia & Lithuania & Tajikistan \\
\hline Costa Rica & Malaysia & Tanzania $^{2}$ \\
\hline Cote d'Ivoire & Mali & Thailand $^{1}$ \\
\hline Croatia & Mauritania & Trinidad and Tobago \\
\hline Czech Republic & Mauritius $^{1}$ & Tunisia \\
\hline Denmark $^{1}$ & Mexico & Turkey $^{2}$ \\
\hline Dominican Republic ${ }^{2}$ & Moldova $^{2}$ & Ukraine \\
\hline Ecuador & Morocco $^{1}$ & United Arab Emirates \\
\hline Egypt, Arab Rep. & Netherlands ${ }^{1}$ & Uruguay \\
\hline El Salvador & New Zealand ${ }^{1}$ & Venezuela, RB \\
\hline Estonia & Nicaragua $^{2}$ & Vietnam \\
\hline Finland $^{1}$ & Norway ${ }^{1}$ & Zambia \\
\hline Gabon & Oman $^{1}$ & Zimbabwe \\
\hline Georgia & Pakistan & \\
\hline
\end{tabular}

${ }^{1}$ Uses IFS terms of trade ${ }^{2}$ Uses UNCTAD/WDI. No superscript implies that the constant and current values from the WDI

data is used.

Table 5. Country sample 


\begin{tabular}{|c|c|c|}
\hline Variable & Source & Description \\
\hline \multicolumn{3}{|l|}{ Exchange Rate Regime } \\
\hline - LYS (defacto) & Levy-Yeyati and Sturzenegger (2005) & Broad 1 to 3 classification \\
\hline \multirow[t]{2}{*}{ - IMF (dejure) } & provided by IMF staff & Various taxonomies \\
\hline & & harmonized by the authors \\
\hline \multicolumn{3}{|l|}{ Import Data } \\
\hline - Raw Material Trade & World Development Indicator & $\begin{array}{l}\text { Share of agricultural, fuel,ores and metals } \\
\text { fuel imp. in total merch imp. }\end{array}$ \\
\hline \multicolumn{3}{|l|}{ Terms of Trade } \\
\hline - ToT IFS & International Financial Statistics & Index, base year $2000(=100)$ \\
\hline - ToT & own calc. based on data from WDI & see description below \\
\hline - net barter ToT & World Development Indicator & Index, base year $2000(=100)$ \\
\hline -ToT UNCTAD & ToT UNCTAD & Index, base year $2000(=100)$ \\
\hline \multicolumn{3}{|l|}{ National Accounts } \\
\hline - Gross Domestic Product & World Development Indicator & real, in local currency and current \\
\hline - Gross Fixed Capital Form. & World Development Indicator & real, in local currency \\
\hline \multicolumn{3}{|l|}{ Foreign Currency Debt } \\
\hline - Total Foreign Currency Liab. & Bank of International Settlement and own calculation & in percent of GDP \\
\hline - (Short Term) External Debt & World Development Indicator & in percent of GNI \\
\hline \multicolumn{3}{|l|}{ Interest Rates } \\
\hline - Money Market or T-Bill & World Development Indicator and National Sources & in percent \\
\hline - Base Country & Shambaugh and supplemented with RR for recent per. & \\
\hline
\end{tabular}

